\title{
Cryptococcus neoformans and Cryptococcus gattii, the Etiologic Agents of Cryptococcosis
}

\author{
Kyung J. Kwon-Chung ${ }^{1}$, James A. Fraser², Tamara L. Doering ${ }^{3}$, Zhuo A. Wang ${ }^{3}$, \\ Guilhem Janbon ${ }^{4}$, Alexander Idnurm ${ }^{5}$, and Yong-Sun Bahn ${ }^{6}$ \\ ${ }^{1}$ Laboratory of Clinical Infectious Diseases, National Institute of Allergy and Infectious Diseases, National \\ Institutes of Health, Bethesda, Maryland 20892 \\ ${ }^{2}$ Australian Infectious Diseases Research Centre, University of Queensland, Brisbane, Queensland 4072, \\ Australia \\ ${ }^{3}$ Department of Molecular Microbiology, Washington University School of Medicine, St. Louis, Missouri 63110 \\ ${ }^{4}$ Unité Biologie et Pathogénicité Fongiques, Institut Pasteur, 75015 Paris, France \\ ${ }^{5}$ Division of Cell Biology and Biophysics, School of Biological Sciences, University of Missouri, Kansas City, \\ Missouri 64110 \\ ${ }^{6}$ Department of Biotechnology, College of Life Science and Biotechnology, Yonsei University, Seoul 120-749, \\ Republic of Korea \\ Correspondence: jkchung@niaid.nih.gov
}

\begin{abstract}
Cryptococcus neoformans and Cryptococcus gattii are the two etiologic agents of cryptococcosis. They belong to the phylum Basidiomycota and can be readily distinguished from other pathogenic yeasts such as Candida by the presence of a polysaccharide capsule, formation of melanin, and urease activity, which all function as virulence determinants. Infection proceeds via inhalation and subsequent dissemination to the central nervous system to cause meningoencephalitis. The most common risk for cryptococcosis caused by $C$. neoformans is AIDS, whereas infections caused by $C$. gattii are more often reported in immunocompetent patients with undefined risk than in the immunocompromised. There have been many chapters, reviews, and books written on $C$. neoformans. The topics we focus on in this article include species description, pathogenesis, life cycle, capsule, and stress response, which serve to highlight the specializations in virulence that have occurred in this unique encapsulated melanin-forming yeast that causes global deaths estimated at more than 600,000 annually.
\end{abstract}

\section{HISTORY OF THE ETIOLOGIC AGENTS AND CRYPTOCOCCOSIS}

Cryptococcus neoformans was first isolated

from peach juice by Sanfelice in 1894 in Italy and was named Saccharomyces neoformans
(Sanfelice 1894). In the same year, Busse provided the first description of a case of cryptococcosis (Busse 1894) and isolated a yeast culture from a sarcoma-like lesion in the infected young woman's tibia. Busse called the fungus Saccharomyces, while naming the disease Sac-

Editors: Arturo Casadevall, Aaron P. Mitchell, Judith Berman, Kyung J. Kwon-Chung, John R. Perfect, and Joseph Heitman Additional Perspectives on Human Fungal Pathogens available at www.perspectivesinmedicine.org

Copyright (C) 2014 Cold Spring Harbor Laboratory Press; all rights reserved; doi: 101101/cshperspect.a019760

Cite this article as Cold Spring Harb Perspect Med 2014;4:a019760 
K.J. Kwon-Chung et al.

charomycosis hominis (Busse 1895). Around the same time, Curtis studied a yeast-like fungus isolated from a tumor in a patient's hip, and, noting its difference from the cultures of both Busse and Sanfelice, described the fungus as Saccharomyces subcutaneous tumefaciens n. sp. (Curtis 1986). Curtis' strain was later determined to be the first clinical isolate of C. gattii (Kwon-Chung et al. 2002). Because the Busse and Sanfelice's strains lacked the sugar fermentation and ascospore formation that are the hallmarks of the genus Saccharomyces, Vuillemin reclassified the yeasts as Cryptococcus hominis and C. neoformans, respectively, in 1901 (Vuillemin 1901). The characteristic neurotropism of C. neoformans was first recognized in 1914 by Versé (1914), and 2 years later by Stoddard and Cutler (1916). However, Stoddard and Cutler called the etiologic agent Torula histolytica and the disease "torulosis" by misinterpreting the fungal capsule as evidence of fungal histolytic action in the host tissue (Kwon-Chung and Bennett 1992). Confusion about the identity of the cryptococcosis agent persisted until Benham performed comprehensive studies with clinical Cryptococcus strains and concluded that all of the strains from human infections belonged to one species with two varieties based on serological differences (Benham 1935, 1950). She proposed to replace "torulosis/torula meningitis" with cryptococcosis and to conserve the fungal name C. neoformans (Benham 1950). Cryptococcal antigenic heterogeneity was confirmed in 1950 by Evans who identified three serotypes: A, B, and C (Evans 1950). A fourth serotype, D, was discovered in 1968 (Wilson et al. 1968).

The environmental source of $C$. neoformans was unknown until Emmons isolated C. neoformans from soil collected in Virginia in 1951, reporting that the pathogen was abundant in pigeon nests and droppings (Emmons 1951, 1955). It took nearly 40 more years to discover the environmental source of $C$. gattii as trees when Ellis reported isolation of serotype $B$ strains from Eucalyptus camaldulensis in Australia in 1990 (Ellis and Pfeiffer 1990).

The laboratory diagnosis of C. neoformans was drastically simplified by the early 1960 s when Seeliger and Staib discovered that C. neoformans could be distinguished from other white clinical yeasts by their urease activity (Seeliger 1956) and melanin formation (Staib $1962 \mathrm{~b}$ ) besides the presence of capsule. By the mid-1970s, the complete life cycles of C. neoformans and $C$. gattii became known when heterothallic sexuality was discovered in both species (Kwon-Chung 1975, 1976b). The discovery of a heterothallic life cycle ushered Cryptococcus into the modern era, facilitating the development of the tools for classical genetic analysis and providing evidence that virulence factors such as capsule and melanin formation followed Mendelian inheritance (Kwon-Chung et al. 1982c). These discoveries were timely, as cryptococcosis had been considered a rare disease until immunosuppressive therapy came into wide use starting in the 1970s. The importance of understanding the pathogen became even more pressing as an unprecedented rate of increase in cryptococcosis began in the early 1980s, with AIDS becoming the leading risk factor of the disease. Building on these critical early advances and the need to develop a deeper understanding to combat this emergent threat, the Cryptococcus community has rapidly expanded into a robust and highly collaborative field of international researchers who have established a broad array of molecular techniques (Edman and Kwon-Chung 1990; Toffaletti et al. 1993; Lodge et al. 1994) and genomic sequences (Loftus et al. 2005; Kronstad et al. 2011) with which to develop a deeper understanding of these deadly pathogens.

\section{TAXONOMY AND NOMENCLATURE OF C. neoformans AND C. gattii}

For several decades, the agents of cryptococcosis were grouped into two varieties that included five serotypes: C. neoformans var. neoformans for serotypes $\mathrm{A}, \mathrm{D}$, and $\mathrm{AD}$ (now known to be a hybrid between A and D strains), and C. neoformans var. gattii for serotypes B and C (KwonChung et al. 1982a). When teleomorphs of the two species were discovered, they were classified in the genus Filobasidiella as Filobasidiella neoformans (serotypes A and D) and F. bacillispora 
(serotype B and C) under the family Filobasidieceae of the order Filobasidiales in Basidiomycota (Kwon-Chung 1975, 1976b). Discoveries of the two distinct teleomorphs were the first steps toward defining what are now recognized as two distinct species, C. neoformans and C. gattii. Molecular phylogenetic studies have since shown that $C$. neoformans and $C$. gattii cluster with the members of the order Tremellales instead of Filobasidiales (Fonseca et al. 2011). Furthermore, although the teleomorph names have been used to denote that both pathogenic species of Cryptococcus belong to a genus within Basidiomycota, its use has been abandoned as of 2013 and only Cryptococcus is used in accordance with the new fungal nomenclatural rule of one name for one fungus (Hawksworth et al. 2011).

After PCR and DNA sequencing became readily accessible, classification of the etiologic agents of cryptococcosis was greatly facilitated by molecular approaches. First, strains of serotype A were recognized as a separate variety, $C$. neoformans var. grubii, from strains of C. neoformans var. neoformans (serotype D), based on the divergence in URA5 gene sequence (Franzot et al. 1999). In 2000, C. neoformans var. gattii was elevated to a species, C. gattii (KwonChung et al. 2002) and the taxon C. neoformans was reserved for the varieties neoformans and grubii. Subsequent molecular clock analysis has estimated that these species diverged approximately 50 million years ago (Ngamskulrungroj et al. 2009a). Genotyping of numerous C. neoformans and C. gattii global strains revealed that each species is composed of at least four major genetically diverse subgroups (Meyer et al. 2011). C. neoformans contains molecular types VNI-VNIV and VNB with var. grubii VNI, VNII, and VNB strains, estimated to have diverged from the single var. neoformans molecular type VNIV (serotype D) approximately 25 million years ago, and serotype AD (VNIII) strains representing hybrids of the two varieties. C. gattii molecular types VGI and VGII usually correspond with serotype $\mathrm{B}$, and molecular types VGIII and VGIV with serotype C; these molecular types have been estimated to have diverged over 8.5-12.5 million years. Fur- thermore, some molecular types may contain subtypes that can be identified by multilocus sequence typing (MLST). For example, $C$. gattii VGII and VGIII include at least two or three subtypes each, VGIIa/VGIIb/VGIIc and VGIIIa/VGIIIb, respectively (Kidd et al. 2004; Byrnes et al. 2010, 2011). Although serotype AD hybrids are common, these are sterile, and hybrids between other molecular types are rare, raising the possibility that each haploid type may in fact represent different species. However, elevating the eight major haploid molecular types to separate species status is controversial at present and a consensus on how to treat the C. neoformans/C. gattii species complex taxonomically has yet to be achieved among medical mycologists (de Hoog et al. 2013).

\section{ECOLOGY}

Although C. neoformans was first isolated from peach juice, the most important saprophytic sources globally are weathered droppings from pigeon (Columba livia) and soil (Emmons 1955). The fungus is not the normal flora of soil; samples positive for C. neoformans have mostly been from areas frequented by pigeons, chickens, turkeys, or occasionally other avian species (Emmons 1955; Ajello 1958). The species has also been recovered from the guano of a range of bird species including canaries, parrots, munia birds, and budgerigars (Staib 1962a; Swinne-Desgain 1975; Bauwens et al. 1986). Although the ecological relationship between C. neoformans and avian species has been globally consistent, the precise link between birds and the cryptococcal natural habitat has yet to be defined. Pigeons are rarely infected because of their high body temperature $\left(41^{\circ} \mathrm{C}-42^{\circ} \mathrm{C}\right)$ exceeding the growth temperature ranges of C. neoformans, but isolation from crops, beaks, or feet suggests that the feed they ingest could be contaminated with the fungus (Littman and Borok 1968; Khan et al. 1977). Recently, arboreal sources of $C$. neoformans have been increasingly reported in various parts of the world. Isolation of $C$. neoformans from the bark, treetrunk hollows, and decaying wood of more than 36 arboreal genera have been reported (Mitchell 
K.J. Kwon-Chung et al.

et al. 2011). The vast majority of environmental strains, regardless of the geographical source, belong to serotype A molecular type VNI. Serotype D molecular type VNIV strains from the environment are mostly from central Europe (Mitchell et al. 2011).

C. gattii, on the other hand, has not been isolated from avian guanos (Kwon-Chung and Bennett 1992; Xu et al. 2000) and subsequent to the first report on the isolation of C. gattii serotype B molecular type VGI strains from E. camaldulensis in Australia (Ellis and Pfeiffer 1990), a growing number of trees have been identified as environmental reservoirs of the species (Stephen et al. 2002; Mitchell et al. 2011), with trees that harbor both cryptococcal pathogens overlapping in various parts of the world (Mitchell et al. 2011). Although both species can infect Arabidopsis thaliana under laboratory conditions (Xue et al. 2007, 2011; Warpeha et al. 2013), cryptococcosis agents are not yet known to cause plant disease in nature. Another important ecologic factor of C. neoformans may be its interaction with other organisms in soil such as various bacteria, amoebas, mites, sow bugs, and worms (Nielson et al. 1978; Ruiz et al. 1981; Steenbergen et al. 2001). In fact, Castellani (1931) first reported isolation of Acanthamoeba castellani as a contaminant of Cryptococcus cultures. The interaction between C. neoformans and soil amoeba is viewed as an important factor for the evolution of C. neoformans as a successful facultative intracellular pathogen. C. neoformans can survive in amoebae and the fungus can utilize the same pathogenic strategy in human macrophages, which in some respect provides a similar environment. It has been proposed that such predation in the environmental niche has selected for the cryptococcal virulence traits that contribute to pathogenesis in human hosts (Steenbergen et al. 2001; Casadevall and Pirofski 2007).

\section{EPIDEMIOLOGY}

Cryptococcosis caused by C. neoformans is worldwide in distribution and the vast majority of patients with symptomatic disseminated infection have an identified underlying immuno- compromised condition (Perfect 2010; Sorrell et al. 2011). As the most common predisposition to cryptococcal meningoencephalitis globally is HIV infection, the rate of cryptococcosis mirrors the spread of the AIDS pandemic; by extension, the highest number of cases occur in sub-Saharan Africa where over 25 million people are living with AIDS (Park et al. 2009, 2011). The global burden of the disease is estimated to be close to 1 million cases with 700,000 deaths annually (Park et al. 2009). Other important known underlying conditions are all associated with a compromised immune status, and include prolonged treatment with corticosteroids, organ transplantation, advanced malignancy, diabetes, sarcoidosis, and idiopathic CD4 lymphocytopenia (Casadevall and Perfect 1998; Perfect 2010). Although the vast majority of patients with disseminated cryptococcosis are immunocompromised, C. neoformans also causes disease in apparently normal hosts. The proportion of "apparently normal" versus immunocompromised patients is significantly higher with C. gattii infection (Chen et al. 2000, 2008; Sorrell et al. 2011). These apparently normal patients could have some unknown immunological defects that are not detected by routine tests employed in clinical laboratories. Recently, GM-CSF-neutralizing autoantibodies were detected in the plasma of otherwise immunocompetent patients with $C$. gattii infection (Saijo et al. 2014), a finding that suggests that expanded immunological tests may uncover hitherto unknown risks in otherwise healthy cryptococcosis patients.

Strains of C. neoformans molecular type VNI are the predominant etiologic agents of cryptococcosis isolated worldwide (63\%) followed by VNII/VNIII (6\% each) and VNIV (5\%) type (Meyer et al. 2011). Regardless of molecular type, global clinical isolates are almost always mating type $\alpha$ (MAT $\alpha)$ except for certain areas in Africa such as Botswana, where MATa can be as common as $10 \%$ of strains (Litvintseva et al. 2003). Consistent with the presence of both mating types in the region, population analysis of clinical isolates has shown evidence of sexual recombination between genetically isolated subgroups of C. neoformans 
serotype A strains from sub-Saharan Africa (Litvintseva et al. 2003).

Cryptococcosis caused by C. gattii is significantly less frequent globally $(<20 \%)$ than C. neoformans ( $80 \%$ ), and the major risk factors for C. gattii infection remain unclear. Distribution of the four major molecular types of C. gattii strains among 2046 cryptococcal isolates from clinical and veterinary sources indicat that the VGI type is most common (9\%) followed by VGII (7\%), VGIII (3\%), and VGIV (1\%) in decreasing order (Meyer et al. 2011). In early studies, C. gattii infection was noted as prevalent only in subtropical and tropical regions and was infrequently found in temperate zones of the world (Kwon-Chung and Bennett 1984, 1992). Although the prevalence of $C$. gattii infection remains more pronounced in the tropical and subtropical parts of the world, recent studies have indicated that the species has expanded to temperate zones. The recent outbreaks of C. gattii infection on Vancouver Island in Canada (Hoang et al. 2004; MacDougall et al. 2007) and the Pacific Northwestern United States (MacDougall et al. 2007; Byrnes and Heitman 2009; Byrnes et al. 2010) are good examples. The Vancouver Island major outbreak strain, VGIIa, and the strains that emerged in the Pacific Northwest, VGIIc, were found to be significantly more virulent in mice than other molecular types of C. gattii (Kidd et al. 2004; Fraser et al. 2005a; Byrnes et al. 2010; D’Souza et al. 2011). Importation of Eucalyptus trees from Australia, the accelerated rate of human international travel, and climate changes may all have contributed to the spread of C. gattii to temperate zones.

\section{HOST RESPONSE AND PATHOGENESIS}

Cryptococcosis begins with inhalation of desiccated airborne yeast cells, or possibly sexually produced basidiospores, into the lungs (Fig. 1). Because the propagules are small $(1.5-3.5 \mu \mathrm{m})$, they reach the distal airways and come into contact with alveolar macrophages. Serologic evidence indicates that cryptococcal infection in humans is prevalent (Goldman et al. 2001) but disease is rare. Activated alveolar macrophages
C. neoformans and C. gattii in Cryptococcosis

recruit other immune cells through cytokines and chemokines and elicit a proper Th1 response and granulomatous inflammation. Our understanding of the host response to cryptococci is mostly based on animal data (Olszewski et al. 2010) and readers are referred to a recent review (Wozniak et al. 2012) for detailed information on host response in the lung.

In a normal host, an effective immune response eliminates most inhaled cryptococci. In contrast, in an immunocompromised host, the cryptococcal cells proliferate, hematogenously disseminate to the brain by crossing the blood-brain barrier (Chang et al. 2004; Shi et al. 2010), and adapt to the suboptimal levels of oxygen and nutritional conditions of the brain to multiply and cause meningoencephalitis (Chang et al. 2007; Chun et al. 2007). Although virtually every organ in the body can be involved, infection of the central nervous system (CNS) is the most common clinical manifestation of cryptococcosis and the most common cause of death. Untreated CNS infection is uniformly fatal (Kwon-Chung and Bennett 1992; Casadevall and Perfect 1998; Perfect 2010). Another commonly occurring cryptococcal infection is the formation of a small lung-lymph complex where yeasts remain viable but dormant and these patients remain clinically asymptomatic (Salyer et al. 1974; Baker 1976) until loss of local immunity resulting from various causes such as corticosteroid treatment, progression of an HIV infection, or other immunosuppressive conditions (Perfect 2010). Upon this loss of immunity, the dormant yeast cells are activated and begin to multiply in the pulmonary-lymph node complex and disseminate into extrapulmonary sites. This reactivation of latent infection has been seen mainly with $C$. neoformans infection as the most common incidence in AIDS patients, contributing to the definition of cryptococcosis as an AIDSdefining illness (Dromer 2011). In contrast, infection caused by C. gattii occurs more often in immunocompetent patients with or without any known underlying conditions (Sorrell et al. 2011). Although C. neoformans primarily presents as meningoencephalitis, pulmonary infection is considerably more common with 
K.J. Kwon-Chung et al.

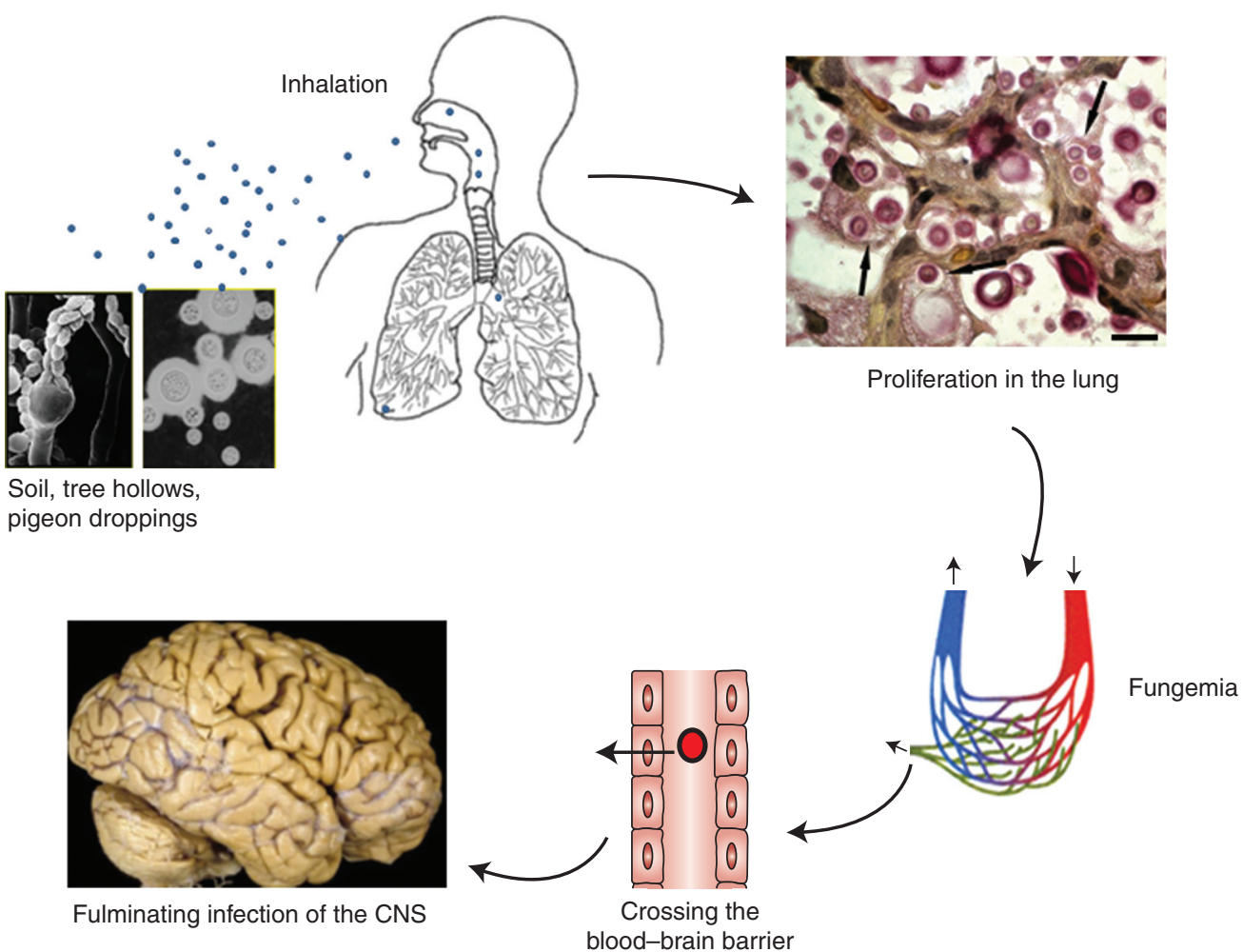

Figure 1. Route of cryptococcal meningoencephalitis. Airborne cryptococcal cells are inhaled by the host and proliferate in the lung before they hematogenously disseminate to the brain.

C. gattii infection (Chen et al. 2000; Galanis et al. 2010). Animal studies supported these differences in the primary target organs between the two species; mice infected with C. neoformans succumbed to infection by CNS infection, whereas mice infected with C. gattii died by pulmonary infection (Ngamskulrungroj et al. 2012c).

\section{TREATMENT AND RESISTANCE TO DRUGS}

The Infectious Diseases Society of America (IDSA) published the "Practice Guidelines for Management of Cryptococcal Disease" in 2000 and an updated version in 2010 (Perfect et al. 2010). Amphotericin B, a secondary metabolite of Streptomyces nodosus, has been the major therapeutic agent for cryptococcal meningoencephalitis since the late 1960s (Sarosi et al. 1969). Although sometimes used alone, it be- came common in the early 1980s to use this polyene in combination with flucytosine, a fluorinated pyrimidine analog (Bennett et al. 1979). Following the release of fluconazole in 1990, the existing regimen of amphotericin B/flucytosine combination for induction therapy was expanded to be followed by maintenance regimens using fluconazole (Perfect et al. 2010). More important, the treatment strategy for cryptococcosis may vary depending on the different categories of risk groups: HIV-infected patients, organ transplant recipients, non-HIV-infected, and nontransplant patients. Specific recommendations also exist for other risk groups such as pregnant women, patients in resourcelimited environments, and those with a C. gattii infection (Perfect et al. 2010). Detailed information on the strategies of treatment and management of cryptococcosis patients are discussed in Whitney and Bicanic (2014). 
There have been a number of reports on cryptococcal resistance to antifungal drugs. Fluconazole resistant strains have been the most common, arising from AIDS patients undergoing long-term azole maintenance therapy (Paugam et al. 1994; Rodero et al. 2003; Pfaller et al. 2011; Sionov et al. 2012). So far, only two fluconazole resistant mutant strains isolated from such patients have been molecularly characterized and both were found to contain a missense mutation in the lanosterol $14 \alpha$ demethylase encoding-ERG11 gene (Rodero et al. 2003; Sionov et al. 2012). Recently, both C. neofomans and C. gattii (Sionov et al. 2009; Varma and KwonChung 2010) have been reported to be innately heteroresistant to azoles. Characterized by the emergence of minor subpopulations in each clone that can adapt to higher concentrations of azoles, this acquired resistance is reversed upon release from drug stress (Sionov et al. 2009, 2010). The lowest level of fluconazole at which the heteroresistant minor subpopulation emerges (LHF) and the frequency of resistant subpopulation varies depending on the strain. A majority of the clinical isolates obtained before the birth of azoles had an LHF of $16 \mu \mathrm{g} / \mathrm{mL}$ or lower (Sionov et al. 2009), whereas the LHF of C. gattii was generally higher (Varma and Kwon-Chung 2010).

Molecular analyses have shown that the emergence of heteroresistant clones is caused by the formation of disomy (two copies) of chromosomes that contain key genes associated with azole resistance. Heteroresistant clones, therefore, are temporary aneuploids in one or more chromosomes (Sionov et al. 2010). Chromosome 1, which contains the genes encoding the azole target Erg11 and the azole efflux pump Afr1 (Posteraro et al. 2003), always duplicates at the lowest azole concentration at which the heteroresistant clones emerge. Consistent with this, emergence of disomic chromosome 1 in yeast cells was observed in vivo in mouse brains during prolonged treatment with fluconazole (Sionov et al. 2013). As drug concentration was increased, chromosome 4 and other chromosomes subsequently duplicated in a stepwise manner to resist the higher drug concentrations (Sionov et al. 2010; Ngamskulrungroj et al. 2012a). Heteroresistance has now been suggested to be the most common cause of azole treatment failure that occurs during suppression therapy in AIDS patients (Sionov et al. 2013).

\section{MYCOLOGY}

\section{Life Cycle}

C. neoformans (Fig. 2) and C. gattii (Fig. 3) are both heterothallic haploid yeasts that exist in two mating types, MAT $\alpha$ and MATa. However, $M A T \alpha$ strains are predominant in nature, and, as a consequence, the vast majority of clinical isolates are MAT $\alpha$ strains (Kwon-Chung and Bennett 1978, 1984; Kidd et al. 2004; Litvintseva et al. 2005; Chen et al. 2008) and the reasons for paucity of MATa strains are unclear. The haploid cells propagate asexually by budding until the strains of opposite mating type come into contact on substrates conducive for mating. Cells of the MATa strains secrete MFa pheromone and MAT $\alpha$ cells secrete MF $\alpha$ pheromone; in response to the mating partner's pheromone, the MATa cells undergo isotropic growth, whereas the MAT $\alpha$ cells form conjugation tubes (McClelland et al. 2004; Stanton et al. 2010; Gyawali and Lin 2013) to enable fusion and produce dikaryotic hyphae with fused clamp connections (Fig. 2E). During the early mating process, mitochondria from the MAT $\alpha$ partner are eliminated by the functions of the transcription factor Mat2 and the homeodomain protein complex Sxi1 $\alpha /$ Sxi2a (Yan et al. 2004; Gyawali and Lin 2013) and only MATa mitochondria are subsequently inherited by the progeny produced from the mating ( $\mathrm{Xu}$ et al. 2000). In the terminal swollen part of the basidium, the two nuclei from opposite mating types fuse to form a single transient diploid nucleus that undergoes one cycle of meiotic division producing four haploid nuclei (KwonChung 1976a, 1980). These meiotic products then repeatedly undergo mitotic division to basipetally bud four long chains of basidiospores (sexual spores) consisting of MAT $\alpha$ and MATa type spores in an equal ratio (Kwon-Chung 1980). These basidiospores can cause infection 
K.J. Kwon-Chung et al.
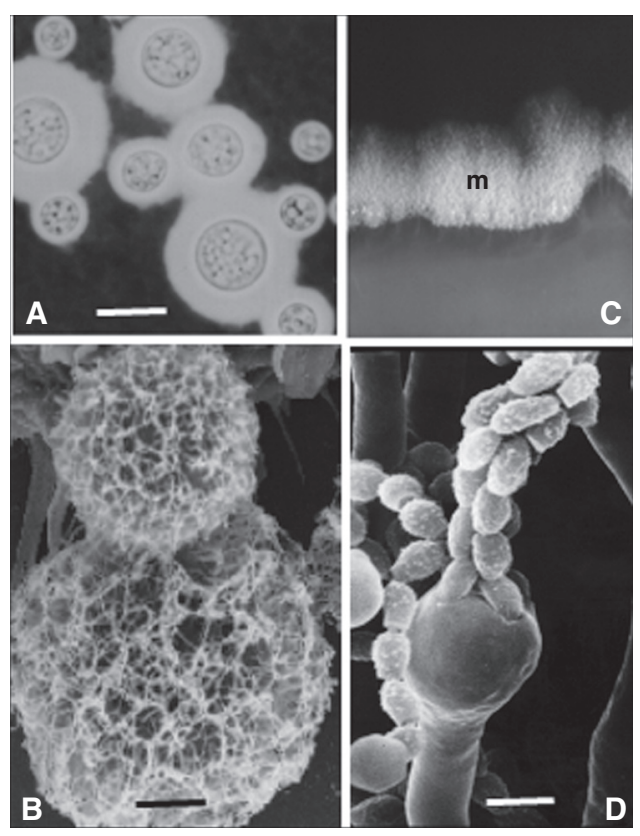

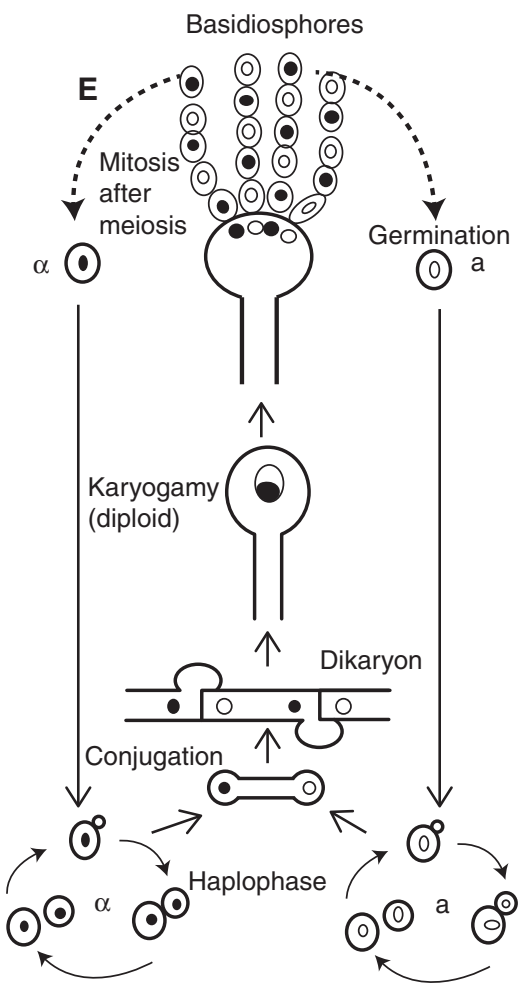

Figure 2. Sexual and asexual states of Cryptococcus neoformans. (A) Yeast cells stained by India ink showing encapsulated globose cells. Scale bar, $5 \mu \mathrm{m}$. (B) Scanning electron micrograph of budding yeast cells (image courtesy of Sabriya Stukes). Scale bar, $1 \mu \mathrm{m}$. (C) Dikaryotic hyphal production (m) at the edge of mated strains between JEC20 (MATa) X JEC21(MAT $)$ ). (D) Scanning electron micrograph of basidia-bearing chains of oval to elliptical basidiospores (Samson et al. 1983). Scale bar, $5 \mu \mathrm{m}$. (E) Life cycle of Cryptococcus neoformans. $\alpha$, cells of MAT $\alpha$ type; a, cells of MATa type.

in a mouse model just as efficiently as vegetative yeast cells, and may play the role of infectious particles (Giles et al. 2009).

Traditional bipolar mating of cells of opposite mating types is not the only sexual cycle available to C. neoformans. In this species, unisexual reproduction has also been described in MAT $\alpha$ strains that results in the four chains of basidiospores morphologically indistinguishable from basidiospores formed by partners of two opposite mating types instead of formed when partners are of opposite mating types (Lin et al. 2005; Ni et al. 2013). Unlike traditional mating, during this process the clamp connections remain unfused (Hsueh et al. 2011b), and by necessity the mitochondria are inherited from a MATa parent (Xu et al. 2000;
Hsueh et al. 2011a; Ni et al. 2013). More intriguing, the developmental cascades for both modes of reproduction have been found to be controlled by the same genetic circuits, demonstrating that the spores produced in unisexual reproduction are also the result of meiosis (Lin et al. 2005; Feretzaki and Heitman 2013). Furthermore, a recent report indicates that monokaryotic hyphal production unrelated to unisexual reproduction can be induced by high-temperature arrest of yeast cell cycle in the $G_{2}$ stage (Fu et al. 2013). Whether the genetic circuits that control monokaryotic hyphal formation induced by high-temperature cell-cycle arrest at $G_{2}$ overlap with those of sexual reproduction is a compelling question that remains to be determined. 


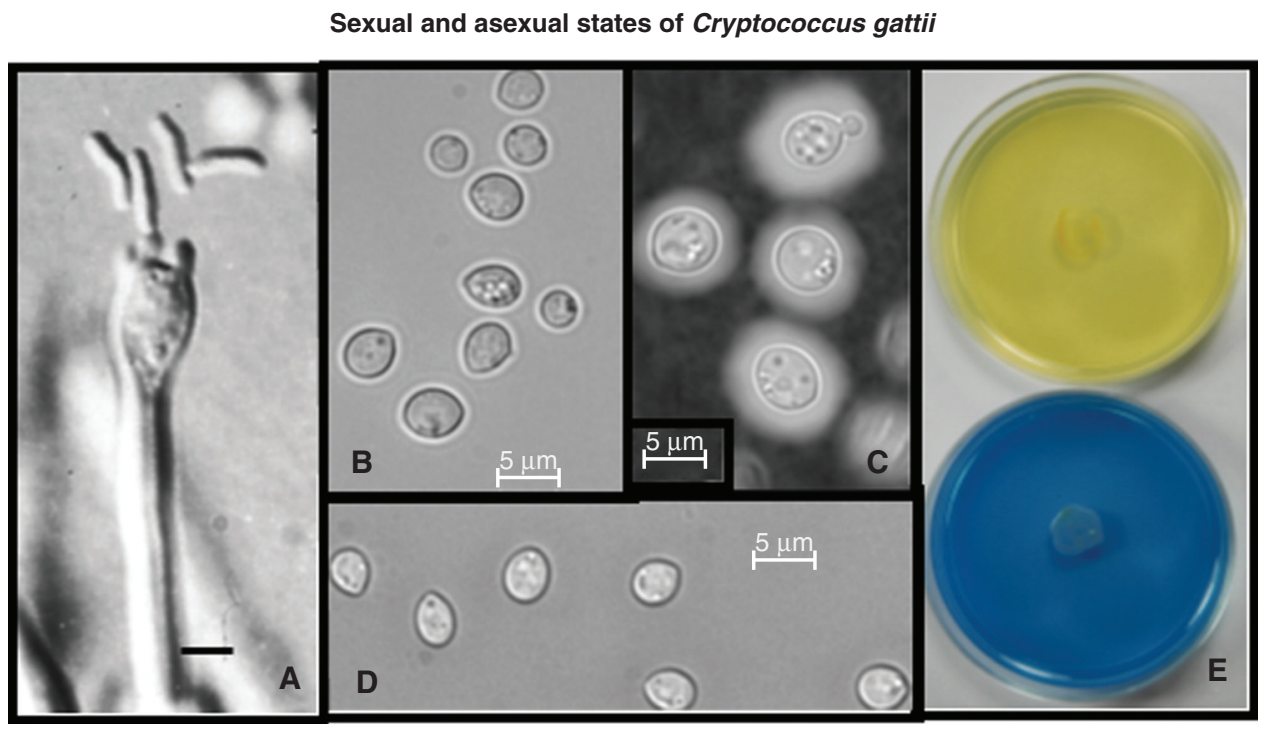

Figure 3. Sexual and asexual states of Cryptococcus gattii. (A) Basisia and basidiospores. Scale bar, $5 \mu \mathrm{m} .(B)$ Globose to oval-shaped yeast cells of R265 (VGII type). (C) India ink-stained yeast cells of NIH319 (VGIII type). (D) Oval- to tear-shaped yeast cells of R-1407 (VGIV type). (E) CGB agar for differentiation of $C$. neoformans (no reaction) from C. gattii (cobalt blue).

Phenotypic Differences between

C. neoformans and C. gattii

The two etiologic agents of cryptococcosis can be differentiated by their teleomorph, serotype, and biochemical characteristics in addition to their epidemiological and ecological differences. Although the morphology of C. neoformans yeast cells are almost uniformly globose, those of C. gattii are a mixture of globose and oblong to elliptical cells (Kwon-Chung et al. 1982a); this proportion of globose to oblong cells in C. gattii is strain dependent (Fig. 3BD). The morphology of the two teleomorphs are even more different: rough-walled oblong to eliptical basidiospores are produced in C. neoformans, whereas the basidiospores produced by $C$. gattii, as suggested by the original teleomorph designation of $F$. bacillispora, are in bacillary form with smooth walls (Fig. 3A) (KwonChung 1975, 1976b). The species are also distinguishable by their considerable differences in their ability to utilize nitrogen (Lee et al. 2011; Ngamskulrungroj et al. 2012b) and carbon sources (Bennett et al. 1978). Taking advantage of their differences in nitrogen assimilation, the widely used one-step diagnostic media canavanine-glycine-bromothymol blue (CGB) agar was formulated to distinguish the two species (Kwon-Chung et al. 1982b). The resistance of C. gattii to L-canavanine and the ability to use glycine as a nitrogen and carbon source (and hence alter the medium $\mathrm{pH}$ ) provides two levels of selection, enabling robust identification of C. gattii strains on CGB medium with growth changing the media color to cobalt blue, whereas CGB agar inoculated with strains of C. neoformans remain unchanged (Fig. 3E). CGB agar medium was instrumental in discovering Eucalyptus camaldulensis as the first environmental source of C. gattii (Ellis and Pfeiffer 1990).

\section{Genotypic Differences between C. neoformans and C. gattii}

The differences between $C$. neoformans and C. gattii, and between their molecular types, are even more obvious at the genomic level. The first basidiomycete to have its genome sequenced to completion, the C. neoformans genome heralded the beginning of the postgenomic era for Cryptococcus (Loftus et al. 2005). 
K.J. Kwon-Chung et al.

This data from the closely related VNIV (serotype D) laboratory strains JEC21 and B-3501A revealed the $20 \mathrm{Mb}$ haploid genome to consist of 14 chromosomes ranging in size from $762 \mathrm{~kb}$ to $2.3 \mathrm{Mb}$ (Fraser et al. 2005b; Loftus et al. 2005). With $>6500$ genes with an average size of $1.9 \mathrm{~kb}$, the chromosomes are extremely generich with the exception of a single large cluster on each composed of degenerating transposons predicted to represent regional centromeres.

The availability of the draft $C$. neoformans var. grubii VNI type strain H99 (Janbon et al. 2014) genome enabled comparisons to soon follow. Dietrich and colleagues revealed via whole genome comparison that the genomes exhibited 85\%-90\% identity with few exceptions (Kavanaugh et al. 2006). Among these were the predicted regional centromeres, conserved in location but highly divergent in sequence consistent with their makeup of degenerating rearranged transposable elements, the highly rearranged subtelomeric regions, and a region where identity between the genomes was $98.5 \%$, evidence of recent introgression of var. neoformans (molecular type, VNIV) genetic material into var. grubii (molecular type VNI). It has subsequently been shown that since the divergence of var. grubii and var. neoformans, few genomic rearrangements have occurred in the var. grubii lineage and even more in var. neoformans (Sun and $\mathrm{Xu}$ 2009; Morrow et al. 2012). Given the known propensity of var. grubii to undergo karyotypic change during the infection process (Perfect et al. 1993; Fries et al. 1996), the small number of changes fixed within the var. grubii population in particular over the past $\sim 25$ million years is remarkable. This suggests that the pathogen undergoes gross chromosomal rearrangements at a massively accelerated pace during infection of the human host.

Consistent with their phylogenetic relationship, comparison of the var. neoformans and var. grubii genome sequences with the genomes of C. gattii VGI strain WM276 and VGIIa strain R265 revealed $\sim 85 \%-87 \%$ identity (D'Souza et al. 2011). Like C. neoformans, C. gattii has 14 chromosomes, and although the predicted centromere locations are conserved, the chromosomes have been rearranged by inversions and balanced translocations. Once again, the regions of lowest conservation are the centromeres and subtelomeres. However, intriguing differences between $C$. neoformans and C. gattii still remain to be discovered. For example, recent work has revealed that in contrast to $C$. neoformans, C. gattii VGII strains have lost the RNAi mechanism (Billmyre et al. 2013).

\section{Virulence Factors}

Early classical genetic studies on virulence determinants focused on the distinctive phenotypic characteristics of these species that were also used for diagnostic purposes (i.e., polysaccharide capsule formation [Jacobson et al. 1982; Rhodes et al. 1982; Kwon-Chung and Rhodes 1986] and melanin formation [Kwon-Chung et al. 1982c; Rhodes et al. 1982 ]). The third trait essential for virulence is the ability to grow at mammalian body temperature (Petter et al. 2001; Perfect 2006). Molecular genetic studies using gene-deletion strains have confirmed the role of these three traits in cryptococcal virulence (Chang and Kwon-Chung 1994; Salas et al. 1996; Odom et al. 1997; Janbon et al. 2001). In fact, the molecular study into the role of capsule as the fungal virulence factor in C. neoformans was the first fulfillment of the molecular Koch's postulates (Chang and KwonChung 1994).

\section{Capsule}

The cryptococcal capsule is anchored by the cell wall, which is composed of glucans, chitin, chitosan, and glycoprotein (Doering 2009; Gilbert et al. 2011). The capsule is composed primarily of two large virulence-implicated repeating polysaccharides (Kumar et al. 2011), glucuronoxylomannan (GXM, 1-7 million Da) and glucuronoxylomannogalactan (GXMGal, $\sim 100,000 \mathrm{Da})$, whose structures are depicted in Figure 4. The capsule may also include mannoproteins, hyaluronic acid, and sialic acid. The capsule is displayed on the cryptococcal surface and component polysaccharides are also shed into the environment. Although it is likely that both forms play roles in pathogenesis, 


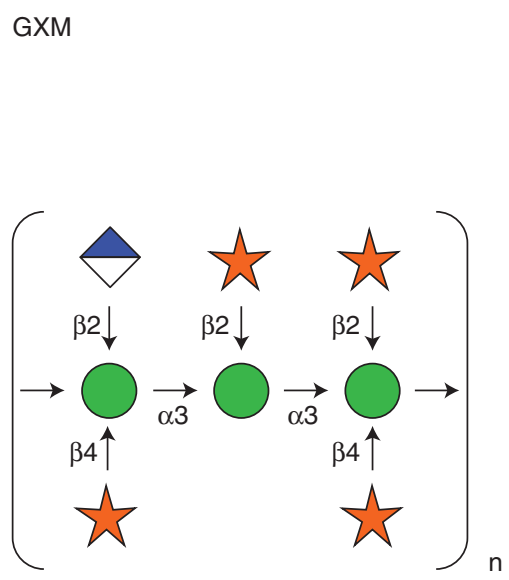

GXMGal

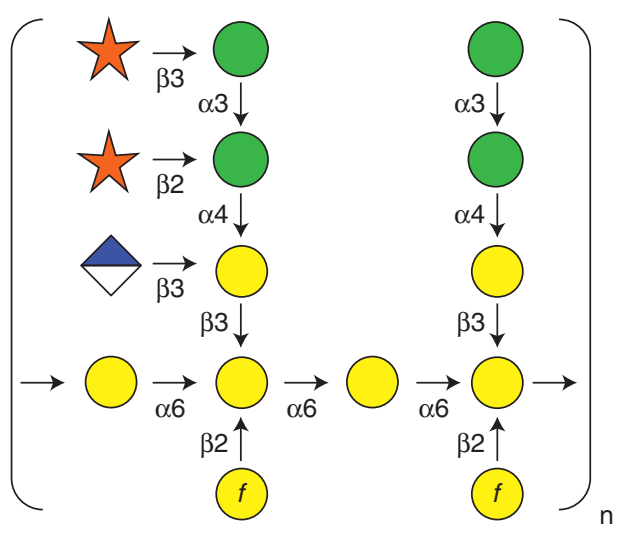

Figure 4. Structures of the cryptococcal capsular polysaccharide. The polymer repeat units of glucuronoxylomannan (GXM) and glucuronoxylomannogalactan (GXMGal) are shown. (Left) The maximally substituted structural reporter group of GXM. Other structural reporter groups vary in the extent and position of xylose addition (Cherniak et al. 1998). Mannose, green spheres; xylose, red stars; glucuronic acid, half-filled diamonds. Mannose acetylation is not shown. (Right) The repeat unit of glucuronoxylomannogalactan (GXMGal) (Vaishnav et al. 1998; Heiss et al. 2009). Trisaccharide side branches on alternate galactose residues may be modified with xylose and glucuronic acid; the two extremes of substitution are shown. Symbols are as above, with galactose as yellow spheres. A fraction of the branched backbone galactoses residues is also modified with $\beta$ 1,2-linked galactofuranose, indicated by $f$; all other residues are in the pyranose form.

most structural work has been done on the shed material, which may differ from that associated with the cell (Frases et al. 2008; Kumar et al. 2011).

Capsule polysaccharides are likely made in the Golgi (Yoneda and Doering 2006; T Doering, unpubl.), requiring synthesis of activated sugar donors, transport of these compounds into the Golgi, polymerization of capsule components, export of product polysaccharides, and assembly at the cell surface (Doering 2009). Based on the capsule structures (Fig. 4), the sugar donors are expected to include GDPmannose, UDP-glucuronate, UDP-xylose, UDPgalactofuranose, and UDP-galactopyranose. Enzymes required for synthesis of the first four have been biochemically characterized, and genes encoding synthetic machinery for all five have been identified and deleted to assess the impact on cells (Bar-Peled et al. 2001, 2004; Wills et al. 2001; Moyrand et al. 2002, 2007, 2008; Griffith et al. 2004; Moyrand and Janbon 2004; Beverley et al. 2005; Doering 2009). The lack of these proteins reduces capsule produc- tion and virulence in animal models, except for the enzyme responsible for UDP-galactofuranose synthesis; this may be because galactofuranose is a minor component of capsule polysaccharides (Heiss et al. 2013). Two nucleotide sugar transporters for GDP-mannose and one for UDP-galactose have also been investigated (Cottrell et al. 2007; Moyrand et al. 2007; Wang et al. 2014). Although the genome encodes other putative nucleotide sugar transporters, they have not been matched to specific functions required for capsule synthesis. The glycosyltransferases that directly mediate capsule synthesis are largely uncharacterized, with only one demonstrated to date (Klutts et al. 2007; Castle et al. 2008; Klutts and Doering 2008). A second enzyme, Cas1, has been suggested to function in capsule polysaccharide acetylation, but its activity has yet to be directly demonstrated (Janbon et al. 2001).

How the capsule is associated with the cell wall and how it grows are outstanding questions in the field. It is clear that an intact cell wall (Gilbert et al. 2010), and, more specifically, 
K.J. Kwon-Chung et al.

cell wall $\alpha$-glucan (Reese and Doering 2003; Reese et al. 2007), is required for capsule association, although whether this is a direct or indirect interaction has not been determined. Chitin has also been implicated in capsule association with the cell wall (Rodrigues et al. 2008; Fonseca et al. 2009), and cations likely play a significant role in intermolecular interactions of capsule polysaccharides that contribute to capsule formation (Nimrichter et al. 2007). Defining the machinery of capsule biosynthesis poses a considerable challenge, because of both the complexity of the process and the difficulty of assigning function to glycoactive enzymes based on sequence alone.

Further biochemical studies and new approaches to gene identification should elucidate this fascinating area.

\section{Genetic Control and Regulation of Capsule Formation and Secretion}

The size and antigenicity of the C. neoformans capsule is dynamic and regulated by the fungus in response to different environmental cues. More important, the in vivo capsule variability suggests an important role for this regulation in the pathophysiology of infection (Dykstra et al. 1977; Granger et al. 1985; Rivera et al. 1998; Chretien et al. 2002; Garcia-Hermoso et al. 2004). In vitro, diverse signals like iron concentration, $\mathrm{CO}_{2}$ level, $\mathrm{pH}$, and nitrogen or glucose concentrations are important modulators of capsule size (Staib et al. 1976; Dykstra et al. 1977; Granger et al. 1985; Vartivarian et al. 1993). Numerous genes functioning in different transduction pathways are necessary for C. neoformans to sense any alteration in its environment. Activation of these pathways induces or alters expression of specific transcription factors necessary for $C$. neoformans to adapt to its new environment. For example, the genes that encode the transcription factors Cirl and HapX are necessary for iron homeostasis and are specifically induced under low iron conditions (Kronstad et al. 2013). Similarly, Rim101 also plays a central role in $\mathrm{pH}$ response and capsule regulation (O'Meara et al. 2010). These studies have also shown that the capsule-regu- lating transduction pathways do not function independently. Rather, significant cross talk exists between them. Activation of the cAMP/ PKA pathway, which can be triggered by altered $\mathrm{CO}_{2}$ levels, low glucose, low nitrogen, or low iron resulting in direct activation of the transcription factor Nrg1, can also result in the regulation of Hog1 and/or Rim101 in response to $\mathrm{pH}$ alteration and osmotic stress, respectively (Bahn et al. 2005b; Cramer et al. 2006; O’Meara et al. 2010). Thus, multiple transduction pathways respond to each environmental signal and a single transduction cascade can respond to multiple signals.

Despite numerous studies on the transcriptional response associated with the activation of these transduction pathways, the genetic basis of capsule size regulation has not been elucidated (Haynes et al. 2011; O'Meara and Alspaugh 2012). This might be a result of the fact that numerous elements of the capsule biosynthetic pathways have still not been identified (Doering 2009). It is also possible that the regulation of capsule size is affected more by secretion than the capsule biosynthetic pathways per se. In fact, the transduction pathways that regulate capsule size also seem to regulate capsule secretion (Choi et al. 2012). However, secretion of the capsule and the genetics of its regulation have not been studied extensively. In the last decade, two C. neoformans Sec proteins, homologous to Saccharomyces cerevisiae proteins necessary for vesicle-mediated exocytic secretion, have been shown to play a major role in GXM secretion (Yoneda and Doering 2006; Panepinto et al. 2009). Although these data support a classical post-Golgi model, a nonconventional capsule secretion pathway has also been identified (Kmetzsch et al. 2011). These data together with the existence of extracellular vesicles containing capsule polysaccharides in C. neoformans suggests an elaborate regulatory mechanism for capsule secretion (Rodrigues et al. 2008; Rodrigues and Djordjevic 2012). Each capsule secretion pathway can presumably result in a different outcome for the capsule polysaccharides. One part might be cell wall linkage (Reese and Doering 2003), and the other is secretion, which is a model supported by some mutations 
that decrease the quantity of the capsule polysaccharide secreted in the environment without affecting capsule size (Kmetzsch et al. 2010), whereas some hypocapsular strains are able to secrete normal levels of polysaccharides (O’Meara et al. 2010). Studies of these two putative pathways might represent a major challenge to the field of capsule genetics in future years.

\section{Melanin Formation}

Melanin is produced by a wide variety of fungal species and the pigment deposited in the cell wall is known to play an important protective role against environmental stress (Nosanchuk and Casadevall 2006). Unlike the black fungi commonly found in soil or on plants, which synthesize dihydroxynaphthalene (DHN) melanin constitutively, C. neoformans produces eumelanin only in the presence of substrates such as 3,4-dihydroxyphenylalanine (DOPA) and other di/polyphenolic compounds (Chasakes 1975; Polacheck et al. 1982). The early observations, using melanin-lacking mutants isolated by UV irradiation, suggesting the importance of melanin as a virulence factor (Kwon-Chung et al. 1982c; Rhodes et al. 1982) was confirmed by the use of $L A C 1$ gene-deletion mutants (Salas et al. 1996). C. neoformans contains two laccase genes, $L A C 1$ and $L A C 2$, in the genome but only $L A C 1$ is expressed significantly under most conditions and virulence is reduced only when the LAC1 gene is deleted (Zhu and Williamson 2004; Pukkila-Worley et al. 2005).The cryptococcal laccase, a member of the multicopper oxidases is localized in the cell walls (Zhu et al. 2001; Waterman et al. 2007b) and its transport to the cell wall is Sec6 dependent (Panepinto et al. 2009). Melanization of cryptococci require numerous additional genes such as the copper transporter $\mathrm{Ccc} 2$, the copper chaperone Atx1, the chitin synthase Chs3, the transcriptional coactivator Mbf1, the chromatin remodeling enzyme Snf5 (Walton et al. 2005), the transcription factor Rim101, and its regulatory gene Rim20 (Liu et al. 2008). As in the case of capsule formation, melanization is regulated by number of different pathways (Liu et al. 2008).
How does melanin provide a survival advantage in the host? There have been numerous studies regarding the role of cryptococcal melanin in protection from phagocytosis (Wang et al. 1995; Liu et al. 1999), killing by host cells (Blasi et al. 1995; Wang et al. 1995), oxidants (Wang and Casadevall 1994; Blasi et al. 1995; Jacobson and Hong 1997), and microbicidal peptides (Doering et al. 1999). In addition, melanin is reported to protect cryptococci from antifungal agents including amphotericin B (Ikeda et al. 2003; Martinez and Casadevall 2006), caspofungin (van Duin et al. 2002; Martinez and Casadevall 2006), and azoles (van Duin et al. 2002, 2004; Ikeda et al. 2003).

\section{Growth at Mammalian Body Temperature}

Although the ability to grow at $37^{\circ} \mathrm{C}$ is not sufficient by itself to be a mammalian pathogen, it is essential for any microbial pathogen to be able to cause invasive disease. The primary reason that both C. neoformans and C. gattii are the only successful pathogens among the more than 70 Cryptococcus species is their ability to grow robustly at physiological temperatures. All the remaining cryptococcal species produce a polysaccharide capsule with or without melanin but fail to grow or grow poorly at $37^{\circ} \mathrm{C}$ (Petter et al. 2001; Fonseca et al. 2011). The first molecular study related to the cryptococcal growth at mammalian body temperature has identified calcineurin, the highly conserved $\mathrm{Ca}^{2+} /$ calmodulin-activated serine/threonine-specific phosphatase encoded by CNA1, to be essential for growth at $37^{\circ} \mathrm{C}$ but not at $24^{\circ} \mathrm{C}$. As a consequence, CNA1 disrupted mutant strains are avirulent (Odom et al. 1997; Fox et al. 2001) and it was proposed that the signaling cascade involving calcineurin is required for cryptococcal pathogenesis (Odom et al. 1997). The importance of calcineurin for cryptococcal growth at $37^{\circ} \mathrm{C}$ but not at $24^{\circ} \mathrm{C}$ also explained the reason why mice treated with cyclosporin $\mathrm{A}$ (CsA), which inhibits signal transduction at $37^{\circ} \mathrm{C}$ but not at $24^{\circ} \mathrm{C}$, are protected from cryptococcosis (Mody et al. 1988) and that CsA is toxic to C. neoformans only at $37^{\circ} \mathrm{C}$ but not at $24^{\circ} \mathrm{C}$ (Odom et al. 1997). Subsequently, many genes 
K.J. Kwon-Chung et al.

required for cryptococcal growth at physiological temperatures and the genes that are significantly up-regulated during growth at elevated temperatures have been identified (Perfect 2006) using various molecular methods such as complementation cloning (Chung et al. 2003), insertional library (Idnurm et al. 2004), genomic-DNA microarrays (Kraus et al. 2004), serial analysis of gene expression (SAGE) (Steen et al. 2002), signature-tagged mutagenesis (Liu et al. 2008), and representational difference analysis (Rosa e Silva et al. 2008). The functions of these genes varied ranging from cell-wall assembly, stress signaling, membrane integrity, basic metabolism, pre-mRNA splicing, chromatin remodeling, and others (Steen et al. 2002; Chung et al. 2003; Kraus et al. 2004; Liu et al. 2008; Rosa e Silva et al. 2008). Functional studies of the genes identified as important for growth at $37^{\circ} \mathrm{C}$, using targeted disruption, showed correlation with low to no infectivity (Kraus et al. 2004; Liu et al. 2008). However, temperatureregulated genes did not necessarily correlate with a temperature-sensitive phenotype (Akhter et al. 2003; Cox et al. 2003).

\section{Degradation Enzymes}

C. neoformans produces many degradation enzymes; some of them have been confirmed as virulence determinants. Urease (Cox et al. 2000, 2001; Osterholzer et al. 2009; Shi et al. 2010; Bahn and Jung 2013; Singh et al. 2013) and phospholipase B (Cox et al. 2001; Ganendren et al. 2006; Wright et al. 2007; Chayakulkeeree et al. 2011) are the two most studied degradation enzymes that have a role in cryptococcal pathogenicity. The functions of these enzymes promote intracellular survival of the yeasts (Wright et al. 2007), hydrolysis of host cell membranes to penetrate into tissue (Chen et al. 1997), immunomodulation (Noverr et al. 2003; Osterholzer et al. 2009), and the enhancement of fungal dissemination from the lung to the brain (Cox et al. 2000; Noverr et al. 2003; Wright et al. 2007; Shi et al. 2010; Singh et al. 2013). Unlike the polysaccharide capsule, however, a lack of these enzymes results in reduced rather than a complete loss of virulence. The correlation between in vitro phospholipase B activity of cryptococcal strains and virulence in mice was first demonstrated in 1997 (Chen et al. 1997) and subsequent work with phospholipase B gene (PLB1)-deletion strains confirmed the importance of the enzyme as a virulence determinant (Cox et al. 2001; Noverr et al. 2003). Phospholipase B is transported to the cell surface in vesicles (Eisenman et al. 2009) and its secretion is dependent upon Sec14, a phosphatidylinositol transfer protein (Chayakulkeeree et al. 2011). Transport of the enzyme to the cell surface enhances adhesion of the cryptococcal cells to human lung epithelial cells, the first step toward initiation of interstitial pulmonary cryptococcosis (Ganendren et al. 2006). It also disrupts the host cell membranes by hydrolysis of the ester linkages on membrane phospholipids, which enables penetration into the host tissue (Chen et al. 2000). Plb1 also supports the intracellular survival of cryptococci within macrophages in connection with lipid metabolism (Wright et al. 2007), which is key for the eventual dissemination of cryptococci to the brain.

Cryptococcal urease activity is important for fungal propagation in the lung as the enzyme promotes accumulation of immature dendritic cells as well as the nonprotective T2 immune response (Osterholzer et al. 2009). Urease activity is also important in the fungus' ability to cross the blood-brain barrier (Olszewski et al. 2004; Shi et al. 2010) by enhancing sequestration of the yeast cells within microcapillary beds (Olszewski et al. 2004). The mechanism of urease activation has been studied extensively in bacteria and plants but rarely in fungi. The cryptococcal urease activation system has recently been deciphered, which showed that the factors required for activation of the urease apoenzyme encoded by URE1 resemble plants more than bacteria (Singh et al. 2013). As with other ureases, the cryptococcal urease is a nickel enzyme and requires the accessory proteins, Ure4, Ure6, and Ure7, which are homologs of the bacterial accessory proteins UreD, UreF, and UreG, respectively. The cryptococcal genome lacks a homolog of bacterial UreE, a nickel chaperone. However, Ure7 (the homolog of bacterial UreG) 
appears to combine the functions of bacterial UreE and UreG. Strains harboring an intact URE1 but disrupted accessory proteins disseminated to the brain at rates similar to the ure 1 mutant, which indicates that it is the urease activity and not the Ure1 protein that is a virulence factor in C. neoformans (Singh et al. 2013). The enzyme appears to require SEC6 for secretion to the surface of the yeast cells (Panepinto et al. 2009).

\section{SENSING AND RESPONDING TO ENVIRONMENTAL VARIABLES}

More recently, other virulence factors have emerged that are being investigated from the perspective of sensing and signaling, often affecting the classical virulence traits. Three recent developments are described below.

The first is metal homeostasis. A role of calcium in signaling in C. neoformans has been well studied in the context of calcineurin signaling (Steinbach et al. 2007), so is not covered further. Iron and copper are the next best-studied metals. Both are relevant to pathogenesis because of their availability to the pathogen, the interconnection between oxygen availability, metal uptake, heme (with iron as a cofactor), and hemedependent sterol biosynthesis. Thus, altered Fe or $\mathrm{Cu}$ homeostasis affects multiple aspects of C. neoformans biology that are clinically relevant, including antifungal drug efficacy. Iron can be either limiting or in excess in a host depending on health status. Effects of iron limitation on $C$. neoformans have been known since the early 1990s, because one consequence is the enhancement of capsule formation (Vartivarian et al. 1993). C. neoformans senses iron levels, and regulates a suite of genes using the Cir1 transcription factor (Jung et al. 2006). Those genes include an adjacent pair of genes for iron oxidation and high-affinity uptake, which are also required for full virulence (Jung et al. 2008, 2009). Other factors, such as the siderophore transporter Sit1, are not required for pathogenesis although this may reflect gene redundancy (Tangen et al. 2007). Another source of iron for C. neoformans is heme, yet use of this iron source is currently less well established (Jung et al. 2010; Cadieux et al. 2013).

The link between copper and melanization has also been known for two decades. For example, mutants impaired in melanin synthesis can be rescued by the addition of copper to the medium (Torres-Guererro and Edman 1994; Walton et al. 2005). Copper is a cofactor for multicopper oxidases, which include the ferroxidase Cfol for iron uptake and laccase for melanin synthesis. Altered copper homeostasis influences these two properties. The MAC1 gene was identified as naturally variable in populations, affecting mating efficiency and melanization (Lin et al. 2006). MAC1 (CUF1) encodes a copper-response transcription factor that regulates target genes (Ding et al. 2011). A fascinating discovery is that the effects of mutation that impair two totally opposite responses to copper (i.e., to low or high $\mathrm{Cu}$ concentrations) are the same. That is, loss of the Ctr 4 transporter for uptake under low Cu concentrations (Waterman et al. 2007a, 2012) or loss of the metallothioneins used in sequestration of $\mathrm{Cu}$ under toxic high concentrations (Ding et al. 2013) both reduced virulence.

Two more recently studied metals are nickel and zinc. Nickel is a cofactor for urease. Like urease deficient strains, those impaired in nickel homeostasis have defects in dissemination after pulmonary infection (Olszewski et al. 2004; Singh et al. 2013). Disruption in C. gattii of the ZAP1 gene, which encodes a zinc sensor and transcription factor, reduces virulence (Schneider et al. 2012). Zinc is a cofactor in many proteins, including zinc finger transcription factors, so loss of virulence may reflect an impact on a number of key processes.

The second example is the impact of gases on pathogenesis. $\mathrm{O}_{2}$ and $\mathrm{CO}_{2}$ vary in concentration in different parts of the body, lower or higher, respectively, than the natural environment in which Cryptococcus species reside. $\mathrm{CO}_{2}$ sensing uses carbonic anhydrase and adenylyl cyclase. Carbonic anhydrases are zinc proteins that convert $\mathrm{CO}_{2}$ to bicarbonate $\left(\mathrm{HCO}^{-}\right)$. Two homologs are expressed in C. neoformans, with Can2 having the major function. Deletion of CAN2 prevents growth under low $\mathrm{CO}_{2}$ concen- 
K.J. Kwon-Chung et al.

trations; however, virulence is unaffected presumably because of the high $\mathrm{CO}_{2}$ concentrations within the host (Bahn et al. 2005a). The other $\mathrm{CO}_{2}$ sensor, adenylyl cyclase (Klengel et al. 2005; Mogensen et al. 2006), synthesizes the signaling molecule cyclic AMP, and is also part of the $\mathrm{G} \alpha$ signaling pathway, and the cac1 mutants are nonpathogenic (Alspaugh et al. 2002).

Concentrations of $\mathrm{O}_{2}$ are sensed by Scp1, a candidate endoplasmic reticulum peptidase. Scpl cleaves the inactive Sre1 into an active transcription factor that is shuttled into the nucleus. Deletion of either gene reduces the ability of $C$. neoformans to grow at $<3 \%$ oxygen levels, and reduces virulence (Chang et al. 2007; Chun et al. 2007). Genes regulated by hypoxia include those for sterol biosynthesis and metal homeostasis. The deleterious effects of low $\mathrm{O}_{2}$ levels are likely in part through altered membrane fluidity. For instance, overexpression of the ERG25 gene for sterol biosynthesis can alleviate the effects of deleting SRE1 (Lee et al. 2007).

The third example is the potential role of light sensing in pathogenesis. Deletion of genes that encode a blue-light-sensing complex reduces virulence (Idnurm and Heitman 2005; Zhu et al. 2013). It is unknown whether darkness represents a specific signal and the relevant genes are also unknown. Although genes for heme biosynthesis and iron uptake are induced by light, the light-sensing mutants do not have phenotypes that indicate any change in these properties (Idnurm and Heitman 2010). Hence, the three best-established virulence traits and growth or stress phenotypes are unaffected, and further analysis may enable discoveries about virulence factors operating in Cryptococcus species.

The three examples above highlight more recent experiments about sensing and signaling to alter pathogenesis. Interacting factors include $\mathrm{pH}$ and nutrient sensing (O'Meara et al. 2010, 2013; Yang et al. 2010). One theme that is emerging is how signals or pathways influence a common set of virulence traits, like the three classical properties of $C$. neoformans, and the potential for cross regulation among them.

\section{SIGNALING PATHWAYS INVOLVED IN STRESS RESPONSE}

In the host environment, cryptococci respond and adapt to the drastic change in conditions by activating stress defense systems such as the high osmolarity glycerol response (HOG), protein kinase $\mathrm{C}(\mathrm{Pkc1}) / \mathrm{MPK} 1 \mathrm{MAPK}$, protein kinase A (Ras, cAMP/PKA), calcineurin, and unfolded protein response (UPR) pathways (Fig. 5). Several studies comparing the stress management between C. neoformans and C. gattii have revealed both redundant and distinct roles of the diverse signaling pathways.

For the initial establishment of infection and cellular proliferation within the host, cryptococci undergo adaptation to host body temperatures. In C. neoformans, in addition to the Ras, calcineurin, and UPR pathways, which play major roles, the HOG and Pkcl/Mpkl pathways also play a significant role in thermotolerance (Bahn and Jung 2013). Interestingly, inhibition of the calcineurin pathway is fungistatic against the highly virulent C. gattii VGIIa strain R265 at $37^{\circ} \mathrm{C}$, whereas it is fungicidal against the less virulent C. gattii VGIIb strain R272 and C. neoformans (Chen et al. 2013). This indicates functional divergence of this pathway among different genotypes of Cryptococcus. Comparative microarray analysis revealed MPK1 to be more up-regulated in R265 than in R272 and its deletion caused temperature sensitivity, defects in cell wall integrity, and a reduced production of melanin and capsule (Ngamskulrungroj et al. 2011). Induction of the nonreducing disaccharide trehalose and transcription of its biosynthetic genes is required for high-temperature growth, which affects the virulence of both C. gattii and C. neoformans (Ngamskulrungroj et al. 2009b). Interestingly, the trehalose pathway modulates production of melanin and capsule as well as cell wall integrity in C. gattii, but not in $C$. neoformans.

Oxidative and nitrosative damage are critical stresses for C. neoformans and C. gattii. During the initial stages of infection and dissemination through the bloodstream, the pathogen needs to survive reactive oxygen species (ROS) 

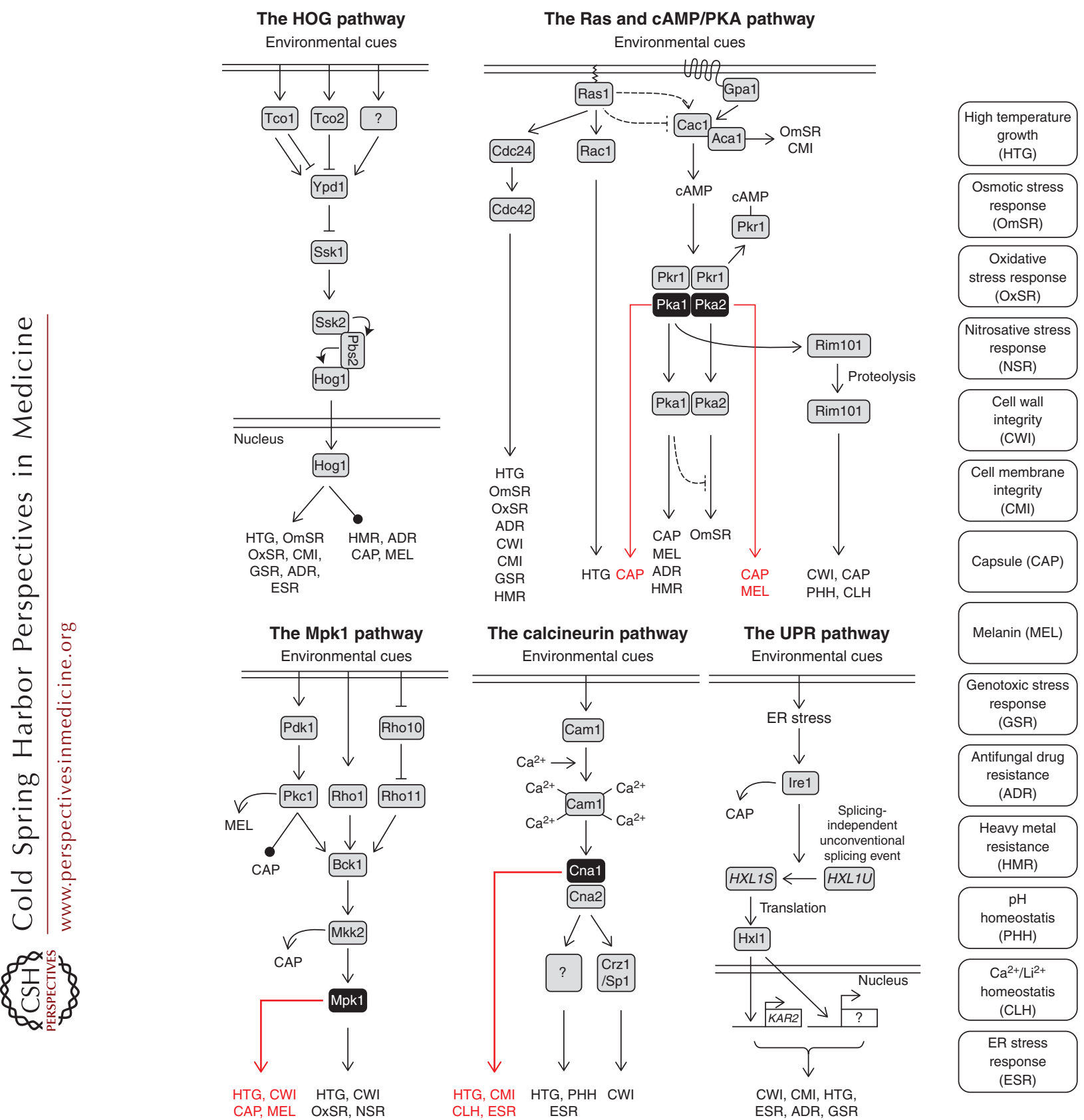

Figure 5. The stress-signaling pathways in C. neoformans and C. gattii. The HOG pathway consists of a phosphorelay system (Tco, hybrid sensor histidine kinase [HHKs]; Ypd1, a His-containing phosphotransfer protein [HPt]; Ssk1, a response regulator [RR]) and a MAPK module; (Ssk2, MAPKKK; Pbs2, MAPKK; Hog1K, MAPK). The Mpk1 MAPK pathway, which is composed of Bck1 MAPKKK, Mkk2 MAPKK, and Mpk1 MAPK, appears to be activated by multiple upstream signaling pathways, including Pkcl and Rho-type GTPases (Rho1, Rho11, and Rho10). Key components of the cAMP/PKA pathway include Cacl and Acal for cAMP production and PKA, which consist of Pkr1 (a regulatory subunit) and Pkal/2 (catalytic subunits). Cacl is

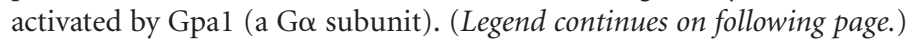


K.J. Kwon-Chung et al.

or reactive nitrogen species (RNS)-rich conditions in macrophages and neutrophils. Similar to other eukaryotes, Cryptococcus contains a series of conserved ROS/RNS defense proteins, including superoxide dismutases (SODs), catalases (Cat1-4), glutathione/thioredoxins, and their peroxidase systems (Brown et al. 2007). In C. gattii, Sod 1 not only counteracts superoxide anions, but also promotes production of virulence factors such as melanin, urease, and phospholipase (Narasipura et al. 2003). To control these ROS and RNS defense systems, C. neoformans primarily utilizes two stress-activated MAPKS: Hog1 and Mpk1 (Bahn et al. 2005b; Gerik et al. 2008). In C. gattii, ROS and RNS defense systems are also important for antifungal drug resistance because itraconazole (but not fluconazole) and amphotericin B induce ROS and RNS production, which causes lipid peroxidation and oxidative degradation of lipid membranes (Ferreira et al. 2013). It is not known whether such events occur in C. neoformans.

The ability to maintain osmotic balance across the cell membrane is related to cation homeostasis and $\mathrm{pH}$ homeostasis within the cell. In fact, a key cation transporter, Enal $\left(\mathrm{Na}^{+} /\right.$ ATPase), which plays an essential role in osmotic stress response, survival under alkaline $\mathrm{pH}$ conditions and plasma membrane potential, is required for virulence of $C$. neoformans (Idnurm et al. 2009; Jung et al. 2012). Following osmotic shock intracellular glycerol synthesis rapidly increases by inducing transcription of glycerol-3-phosphate dehydrogenases genes to counteract external osmotic pressures. Major controllers of these defense systems in C. neoformans include the HOG and Rim101 pathways (Ko et al. 2009; O’Meara et al. 2010). The corresponding pathways in C. gattii have not been characterized.

Finally, upon entering the host, Cryptococcus is subjected to drastic changes in $\mathrm{CO}_{2}$ levels from $0.0036 \%$ (ambient air) to 5\%. High $\mathrm{CO}_{2}$ levels also induce the capsule. To survive in low $\mathrm{CO}_{2}$ conditions, Cryptococcus employs carbonic anhydrases, which catalyze the reversible interconversion between $\mathrm{CO}_{2} / \mathrm{H}_{2} \mathrm{O}$ and $\mathrm{HCO}_{3}^{-} / \mathrm{H}^{+}$ that occurs spontaneously under high $\mathrm{CO}_{2}$ conditions (Bahn et al. 2005a). Therefore, carbonic anhydrases do not affect virulence of Cryptococcus within the host, but may influence its survival on the outer surface (e.g., the skin) of the host and in the natural environment. Similar carbonic anhydrases are observed in C. gattii, but their functions are not known.

\section{CONCLUDING REMARKS}

The Cryptococcus field has made significant progress on all fronts, which includes basic biology, laboratory identification of different molecular types, mechanisms involved in pathogenesis, fungal-host interactions, and challenges in adaptive resistance incurred during long-term therapy for improved clinical outcome. A recent report on the detection of cytokine neutralizing autoantibodies in otherwise immunocompetent patients with C. gattii infection suggests the need of expanded immunological tests to uncover unknown risk factors in otherwise healthy cryptococcosis patients. There are a number of genetically diverged subspecies within each agent of cryptococcosis. Accurate identification of the subspecies is not only of taxonomic interest but may be clinically relevant because patients infected by these subspecies could have varying risk factors.

Figure 5. (Continued) Rim101 is a PKA-dependent transcription factor, which undergoes proteolysis for activation. Ras1 signaling bifurcates into Rac1, a G protein of the Rho family, and Cdc24, a guanine nucleotide exchange (GEF) factor. The calmodulin protein Cam1 binds $\mathrm{Ca}^{2+}$ via four EF-hand motifs and activates the Ser/ Thr-specific phosphatase, calcineurin, which consists of Cnal (a catalytic A subunit) and Cnb1 (a regulatory B subunit). The UPR pathway is composed of the Ire1 kinase, the bZIP transcription factor Hxl1, and their target genes, including KAR2. The described component functions of the signaling pathways are mainly derived from C. neoformans var. grubii. The components characterized in both C. gattii as well as C. neoformans are indicated in black boxes. The functions of these components in C. gattii are marked by a red line. Dotted arrows or line indicate potential but unclear regulation. 


\section{ACKNOWLEDGMENTS}

K.J.K-C. is supported by the Intramural Research Program of the National Institute of Allergy and Infectious Diseases (NIAID), National Institutes of Health, Bethesda, MD and Y.-S.B. is supported by the National Research Foundation of Korea Grant Nos. 20080061963 and 2010-0029117 from MEST. T.L.D. is supported by NIAID Grant Nos. 78795, 87794, 102882, and 109623.

\section{REFERENCES}

Ajello L. 1958. Occurrence of Cryptococcus neoformans in soil. Am J Hyg 67: 72-77.

Akhter S, McDade HC, Gorlach JM, Heinrich G, Cox GM, Perfect JR. 2003. Role of alternative oxidase gene in pathogenesis of Cryptococcus neoformans. Infect Immun 71: 5794-5802.

Alspaugh JA, Pukkila-Worley R, Harashima T, Cavallo LM, Funnell D, Cox GM, Perfect JR, Kronstad JW, Heitman J. 2002. Adenylyl cyclase functions downstream of the $\mathrm{G} \alpha$ protein Gpal and controls mating and pathogenicity of Cryptococcus neoformans. Eukaryot Cell 1: 75-84.

Bahn YS, Jung KW. 2013. Stress signaling pathways for the pathogenicity of Cryptococcus. Eukaryot Cell 12: 15641577.

Bahn Y-S, Cox GM, Perfect JR, Heitman J. 2005a. Carbonic anhydrase and $\mathrm{CO}_{2}$ sensing during Cryptococcus neoformans growth, differentiation, and virulence. Curr Biol 15: 2013-2020.

Bahn YS, Kojima K, Cox GM, Heitman J. 2005b. Specialization of the HOG pathway and its impact on differentiation and virulence of Cryptococcus neoformans. Mol Biol Cell 16: 2285-2300.

Baker RD. 1976. The primary pulmonary lymph node complex of crytptococcosis. Am J Clin Pathol 65: 83-92.

Bar-Peled M, Griffith CL, Doering TL. 2001. Functional cloning and characterization of a UDP-glucuronic acid decarboxylase: The pathogenic fungus Cryptococcus neoformans elucidates UDP-xylose synthesis. Proc Natl Acad Sci 98: 12003-12008.

Bar-Peled M, Griffith CL, Ory JJ, Doering TL. 2004. Biosynthesis of UDP-GlcA, a key metabolite for capsular polysaccharide synthesis in the pathogenic fungus Cryptococcus neoformans. Biochem J 381: 131-136.

Bauwens L, Charles A, Bekker LG. 1986. Isolation of Cryptococcus neoformans var. neoformans in the aviaries of the Antwerp zoological gardens. Mykosen 29: 291-294.

Benham RW. 1935. Cryptococci, their identification by morphology and serology. J Infect Dis 57: 255-274.

Benham RW. 1950. Cryptococcosis and blastomycosis. Ann NY Acad Sci 50: 1299-1314.

Bennett JE, Kwon-Chung KJ, Theodore TS. 1978. Biochemical differences between serotypes of Cryptococcus neoformans. Sabouraudia 16: 168-175.
Bennett JE, Dismukes WE, Duma RJ, Medoff G, Sande MA, Gallis H, Leonard J, Fields BT, Bradshaw M, Haywood H, et al. 1979. A comparison of amphotericin B alone and combined with flucytosine in the treatment of cryptoccal meningitis. N Engl J Med 301: 126-131.

Beverley SM, Owens KL, Showalter M, Griffith CL, Doering TL, Jones VC, McNeil MR. 2005. Eukaryotic UDP-galactopyranose mutase (GLF gene) in microbial and metazoal pathogens. Eukaryot Cell 4: 1147-1154.

Billmyre RB, Calo S, Feretzaki M, Wang X, Heitman J. 2013. RNAi function, diversity, and loss in the fungal king dom. Chromosome Res 21: 561-572.

Blasi E, Barluzzi R, Mazzolla R, Tancini B, Saleppico S, Puliti M, Pitzurra L, Bistoni F. 1995. Role of nitric oxide and melanogenesis in the accomplishment of anticryptococcal activity by the BV-2 microglial cell line. J Neuroimmunol 58: 111-116.

Brown SM, Campbell LT, Lodge JK. 2007. Cryptococcus neoformans, a fungus under stress. Curr Opin Microbiol 10: 320-325.

Busse O. 1894. Uber parasitare Zelleinschlusse und ihre Zuchtung [About parasitic cell enclosures and their generation]. Z Bacteriol 16: 175-180.

Busse O. 1895. Uber Saccharomycosis hominis [About Saccharomycosis hominis]. Virchows Arch A 140: 23-46.

Byrnes EJ, Heitman J. 2009. Cryptococcus gattii outbreak expands into the Northwestern United States with fatal consequences. F1000 Biol Rep 6262.

Byrnes EJ, Li W, Lewit Y, Ma H, Voelz K, Ren P, Carter DA, Chaturvedi V, Bildfell RJ, May RC, et al. 2010. Emergence and pathogenicity of highly virulent Cryptococcus gattii genotypes in the northwest United States. PLoS Pathog 6: e1000850.

Byrnes EJ 3rd, Bartlett KH, Perfect JR, Heitman J. 2011. Cryptococcus gattii: An emerging fungal pathogen infecting humans and animals. Microbes Infect 13: 895-907.

Cadieux B, Lian T, Hu G, Wang J, Biondo C, Teti G, Liu V, Murphy ME, Creagh AL, Kronstad JW. 2013. The Mannoprotein Cigl supports iron acquisition from heme and virulence in the pathogenic fungus Cryptococcus neoformans. J Infect Dis 207: 1339-1347.

Casadevall A, Perfect JR. 1998. Cryptococcus neoformans. ASM, Washington, DC.

Casadevall A, Pirofski LA. 2007. Accidental virulence, cryptic pathogenesis, Martians, lost hosts, and the pathogenicity of environmental microbes. Eukaryot Cell 6: 21692174.

Castellani A. 1931. An amoeba growing in culture of a yeast. J Trop Med Hyg 33: 188-191.

Castle SA, Owuor EA, Thompson SH, Garnsey MR, Klutts JS, Doering TL, Levery SB. 2008. $\beta 1$,2-Xylosyltransferase Cxtlp is solely responsible for xylose incorporation into Cryptococcus neoformans glycosphingolipids. Eukaryot Cell 7: 1611-1615.

Chang YC, Kwon-Chung KJ. 1994. Complementation of a capsule-deficient mutation of Cryptococcus neoformans restores its virulence. Mol Cell Biol 14: 4912-4919.

Chang YC, Stins MF, McCaffery MJ, Miller GF, Pare DR, Dam T, Paul-Satyaseela M, Kim KS, Kwon-Chung KJ. 2004. Cryptococcal yeast cells invade the central nervous 
K.J. Kwon-Chung et al.

system via transcellular penetration of the blood-brain barrier. Infect Immun 72: 4985-4995.

Chang YC, Bien CM, Lee H, Espenshade PJ, Kwon-Chung KJ. 2007. Srelp, a regulator of oxygen sensing and sterol homeostasis, is required for virulence in Cryptococcus neoformans. Mol Microbiol 64: 614-629.

Chaskes S, Tyndall RL. 1975. Pigment production by Cryptococcus neoformans from para- and ortho-diphenols: Effect of the nitrogen source. J Clin Microbiol 1: 500-514.

Chayakulkeeree M, Johnston SA, Oei JB, Lev S, Williamson PR, Wilson CF, Zuo X, Leal AL, Vainstein MH, Meyer W, et al. 2011. SEC14 is a specific requirement for secretion of phospholipase B1 and pathogenicity of Cryptococcus neoformans. Mol Microbiol 80: 1088-1101.

Chen SC, Muller M, Zhou JZ, Wright LC, Sorrell TC. 1997. Phospholipase activity in Cryptococcus neoformans: A new virulence factor? J Infect Dis 175: 414-420.

Chen S, Sorrell T, Nimmo G, Speed B, Currie B, Ellis D, Marriott D, Pfeiffer T, Parr D, Byth K. 2000. Epidemiology and host- and variety-dependent characteristics of infection due to Cryptococcus neoformans in Australia and New Zealand. Australasian Cryptococcal Study Group. Clin Infect Dis 31: 499-508.

Chen J, Varma A, Diaz MR, Litvintseva AP, Wollenberg KK, Kwon-Chung KJ. 2008. Cryptococcus neoformans strains and infection in apparently immunocompetent patients, China. Emerg Infect Dis 14: 755-762.

Chen Y-L, Lehman VN, Lewit Y, Averette AF, Heitman J. 2013. Calcineurin governs thermotolerance and virulence of Cryptococcus gattii. G3 (Bethesda) 3: 527-539.

Cherniak R, Valafar H, Morris LC, Valafar F. 1998. Cryptococcus neoformans chemotyping by quantitative analysis of $1 \mathrm{H}$ nuclear magnetic resonance spectra of glucuronoxylomannans with a computer-simulated artificial neural network. Clin Diagn Lab Immunol 5: 146-159.

Choi J, Vogl AW, Kronstad JW. 2012. Regulated expression of cyclic AMP-dependent protein kinase A reveals an influence on cell size and the secretion of virulence factors in Cryptococcus neoformans. Mol Microbiol 85: 700-715.

Chretien F, Lortholary O, Kansau I, Neuville S, Gray F, Dromer F. 2002. Pathogenesis of cerebral Cryptococcus neoformans infection after fungemia. J Infect Dis 186: 522-530.

Chun CD, Liu OW, Madhani HD. 2007. A link between virulence and homeostatic responses to hypoxia during infection by the human fungal pathogen Cryptococcus neoformans. PLoS Pathog 3: e22.

Chung S, Mondon P, Chang YC, Kwon-Chung KJ. 2003. Cryptococcus neoformans with a mutation in the tetratricopeptide repeat-containing gene, $C C N 1$, causes subcutaneous lesions but fails to cause systemic infection. Infect Immun 71: 1988-1994.

Cottrell TR, Griffith CL, Liu H, Nenninger AA, Doering TL. 2007. The pathogenic fungus Cryptococcus neoformans expresses two functional GDP-mannose transporters with distinct expression patterns and roles in capsule synthesis. Eukaryot Cell 6: 776-785.

Cox GM, Mukherjee J, Cole GT, Casadevall A, Perfect JR. 2000. Urease as a virulence factor in experimental cryptococcosis. Infect Immun 68: 443-448.
Cox GM, McDade HC, Chen SC, Tucker SC, Gottfredsson M, Wright LC, Sorrell TC, Leidich SD, Casadevall A, Ghannoum MA, et al. 2001. Extracellular phospholipase activity is a virulence factor for Cryptococcus neoformans. Mol Microbiol 39: 166-175.

Cox GM, Harrison TS, McDade HC, Taborda CP, Heinrich G, Casadevall A, Perfect JR. 2003. Superoxide dismutase influences the virulence of Cryptococcus neoformans by affecting growth within macrophages. Infect Immun 71: $173-180$.

Cramer KL, Gerrald QD, Nichols CB, Price MS, Alspaugh JA. 2006. Transcription factor Nrg1 mediates capsule formation, stress response, and pathogenesis in Cryptococcus neoformans. Eukaryotic Cell 5: 1147-1156.

Curtis F. 1986. Contribution a l'etude de la saccharomycose humaine [Contribution to the study of human saccharomycosis]. Ann Inst Pasteur 10: 449-468.

de Hoog GS, Hasse G, Chaturvedi V, Walsh TJ, Meyer W, Lackner M. 2013. Taxonomy of medically important fungi in the molecular era. Lancet Infect Dis 13: 385-386.

Ding C, Yin J, Tovar EM, Fitzpatrick DA, Higgins DG, Thiele DJ. 2011. The copper regulon of the human fungal pathogen Cryptococcus neoformans H99. Mol Microbiol 81: $1560-1576$.

Ding C, Festa RA, Chen YL, Espart A, Palacios O, Espin J, Capdevila M, Atrian S, Heitman J, Thiele DJ. 2013. Cryptococcus neoformans copper detoxification machinery is critical for fungal virulence. Cell Host Microbe 13: 265276.

Doering TL. 2009. How sweet it is! Cell wall biogenesis and polysaccharide capsule formation in Cryptococcus neoformans. Annu Rev Microbiol 63: 223-247.

Doering TL, Nosanchuk JD, Roberts WK, Casadevall A. 1999. Melanin as a potential cryptococcal defence against microbicidal proteins. Med Mycol 37: 175-181.

Dromer F, Casadevall A, Perfect JR, Sorrell T. 2011. Cryptococcus neoformans: Latency and disease. In Cryptococcus: From human pathogen to model yeast (ed. Heitman J, et al.), pp. 431-439. ASM, Washington, DC.

D'Souza CA, Kronstad JW, Taylor G, Warren R, Yuen M, Hu G, Jung WH, Sham A, Kidd SE, Tangen K, et al. 2011. Genome variation in Cryptococcus gattii, an emerging pathogen of immunocompetent hosts. mBio 2: e00342-10.

Dykstra MA, Friedman L, Murphy JW. 1977. Capsule size of Cryptococcus neoformans: Control and relationship to virulence. Infect Immun 16: 129-135.

Edman JC, Kwon-Chung KJ. 1990. Isolation of the URA5 gene from Cryptococcus neoformans var. neoformans and its use as a selective marker for transformation. Mol Cell Biol 10: 4538-4544.

Eisenman HC, Frases S, Nicola AM, Rodrigues ML, Casadevall A. 2009. Vesicle-associated melanization in Cryptococcus neoformans. Microbiol 155: 3860-3867.

Ellis DH, Pfeiffer TJ. 1990. Natural habitat of Cryptococcus neoformans var. gattii. J Clin Microbiol 28: 1642-1644.

Emmons CW. 1951. Isolation of Cryptococcus neoformans from soil. J Bacteriol 62: 685-690.

Emmons CW. 1955. Saprophytic sources of Cryptococcus neoformans associated with the pigeon (Columba livia). Am J Hyg 62: 227-232. 
Evans EE. 1950. The antigenic composition of Cryptococcus neoformans: 1. A serologic classification by means of the capsular and agglutination reactions. J Immunol 64: 423-430.

Feretzaki M, Heitman J. 2013. Genetic circuits that govern bisexual and unisexual reproduction in Cryptococcus neoformans. PLoS Genet 9: e1003688.

Ferreira GF, Baltazar Lde M, Santos JR, Monteiro AS, Fraga LA, Resende-Stoianoff MA, Santos DA. 2013. The role of oxidative and nitrosative bursts caused by azoles and amphotericin B against the fungal pathogen Cryptococcus gattii. J Antimicrobial Chemother 68: 1801-1811.

Fonseca FL, Nimrichter L, Cordero RJ, Frases S, Rodrigues J, Goldman DL, Andruszkiewicz R, Milewski S, Travassos LR, Casadevall A, et al. 2009. Role for chitin and chitooligomers in the capsular architecture of Cryptococcus neoformans. Eukaryot Cell 8: 1543-1553.

Fonseca A, Boekhout T, Fell JW. 2011. Cryptococcus Vuillemin (1901). In The yeasts: A taxonomic study, Vol. 3 (ed. Kurtzman CP, Fell JW, Boekhout T), pp. 1661-1745. Elsevier, Amsterdam.

Fox DS, Cruz MC, Sia RA, Ke H, Cox GM, Cardenas ME, Heitman J. 2001. Calcineurin regulatory subunit is essential for virulence and mediates interactions with FKBP12-FK506 in Cryptococcus neoformans. Mol Microbiol 39: 835-849.

Franzot SP, Salkin IF, Casadevall A. 1999. Cryptococcus neoformans var grubii: Separate varietal status for Cryptococcus neoformans serotype A. J Clin Microbiol 37: 838-840.

Fraser JA, Giles SS, Wenink EC, Geunes-Boyer SG, Wright JR, Diezmann S, Allen A, Stajich JE, Dietrich FS, Perfect JR, et al. 2005a. Same-sex mating and the origin of the Vancouver Island Cryptococcus gattii outbreak. Nature 437: $1360-1364$.

Fraser JA, Huang JC, Pukkila-Worley R, Alspaugh JA, Mitchell TG, Heitman J. 2005b. Chromosomal translocation and segmental duplication in Cryptococcus neoformans. Eukaryot Cell 4: 401-406.

Frases S, Nimrichter L, Viana NB, Nakouzi A, Casadevall A. 2008. Cryptococcus neoformans capsular polysaccharide and exopolysaccharide fractions manifest physical, chemical, and antigenic differences. Eukaryot Cell 7: 319-327.

Fries BC, Chen F, Currie BP, Casadevall A. 1996. Karyotype instability in Cryptococcus neoformans infection. J Clin Microbiol 34: 1531-1534.

Fu J, Morris IR, Wickes BL. 2013. The production of monokaryotic hyphae by Cryptococcus neoformans can be induced by high temperature arrest of the cell cycle and is independent of same-sex mating. PLoS Pathog 9: e1003335.

Galanis E, Macdougall L, Kidd S, Morshed M. 2010. Epidemiology of Cryptococcus gattii, British Columbia, Canada, 1999-2007. Emerg Infect Dis 16: 251-257.

Ganendren R, Carter E, Sorrell T, Widmer F, Wright L. 2006. Phospholipase B activity enhances adhesion of Cryptococcus neoformans to a human lung epithelial cell line. Microbes Infect 8: 1006-1015.

Garcia-Hermoso D, Dromer F, Janbon G. 2004. Cryptococcus neoformans capsule structure evolution in vitro and during murine infection. Infect Immun 72: 3359-3365.
Gerik KJ, Bhimireddy SR, Ryerse JS, Specht CA, Lodge JK. 2008. PKC1 is essential for protection against both oxidative and nitrosative stresses, cell integrity, and normal manifestation of virulence factors in the pathogenic fungus Cryptococcus neoformans. Eukaryot Cell 7: 16851698.

Gilbert NM, Donlin MJ, Gerik KJ, Specht CA, Djordjevic JT, Wilson CF, Sorrell TC, Lodge JK. 2010. KRE genes are required for $\beta$-1,6-glucan synthesis, maintenance of capsule architecture and cell wall protein anchoring in Cryptococcus neoformans. Mol Microbiol 76: 517-534.

Gilbert NM, Lodge JK, Specht CA. 2011. The cell wall of Cryptococcus. In Cryptococcus, from human pathogen to model yeast (ed. Heitman J, et al.), pp. 67-79. ASM, Washington, DC.

Giles SS, Dagenais TR, Botts MR, Keller NP, Hull CM. 2009. Elucidating the pathogenesis of spores from the human fungal pathogen Cryptococcus neoformans. Infect Immun 77: 3491-3500.

Goldman DL, Khine H, Abadi J, Lindenberg DJ, Pirofski L, Niang R, Casadevall A. 2001. Serologic evidence for Cryptococcus neoformans infection in early childhood. Pediatrics 107: e66.

Granger DL, Perfect JR, Durack DT. 1985. Virulence of Cryptococcus neoformans. Regulation of capsule synthesis by carbon dioxide. J Clin Invest 76: 508-516.

Griffith CL, Klutts JS, Zhang L, Levery SB, Doering TL. 2004. UDP-glucose dehydrogenase plays multiple roles in the biology of the pathogenic fungus Cryptococcus neoformans. J Biol Chem 279: 51669-51676.

Gyawali R, Lin X. 2013. Prezygotic and postzygotic control of uniparental mitochondrial DNA inheritance in Cryptococcus neoformans. mBio 4: e00112-00113.

Hawksworth DL, Crous PW, Redhead SA. 2011. The Amsterdam declaration on fungal nomenclature. IMA Fungus 2: 105-112.

Haynes BC, Skowyra ML, Spencer SJ, Gish SR, Williams M, Held EP, Brent MR, Doering TL. 2011. Toward an integrated model of capsule regulation in Cryptococcus neoformans. PLoS Pathog 7: e1002411.

Heiss C, Klutts JS, Wang Z, Doering TL, Azadi P. 2009 The structure of Cryptococcus neoformans galactoxylomannan contains [beta]-D-glucuronic acid. Carbohydr Res 344: 915-920.

Heiss C, Skowyra ML, Liu H, Klutts JS, Wang Z, Williams M, Srikanta D, Beverley SM, Azadi P, Doering TL. 2013. Unusual galactofuranose modification of a capsule polysaccharide in the pathogenic yeast Cryptococcus neoformans. J Biol Chem 288: 10994-11003.

Hoang LM, Maguire JA, Doyle P, Fyfe M, Roscoe DL. 2004. Cryptococcus neoformans infections at Vancouver Hospital and Health Sciences Centre (1997-2002): Epidemiology, microbiology and histopathology. J Med Microbiol 53: $935-940$.

Hsueh Y-P, Metin B, Findley K, Rodriguez-Carres M, Heitman J. 2011a. The mating type locus of Cryptococcus: Evolution of genetic clusters governing sex determination and sexual reproduction from the phylogenomic perspective. In Cryptococcus: From human pathogen to model yeast (ed. Heitman J, et al.), pp. 139-149. ASM, Washington, DC. 
K.J. Kwon-Chung et al.

Hsueh YP, Lin X, Kwon-Chung KJ, Heitman J. 2011b. Sexual reproduction of Cryptococcus. In Cryptococcus: From human pathogen to model yeast (ed. Heitman J, et al.), pp. 81-96. ASM, Washington, DC.

Idnurm A, Heitman J. 2005. Light controls growth and development via a conserved pathway in the fungal kingdom. PLoS Biol 3: 615-626.

Idnurm A, Heitman J. 2010. Ferrochelatase is a conserved downstream target of the blue light-sensing white collar complex in fungi. Microbiol 156: 2393-2407.

Idnurm A, Reedy JL, Nussbaum JC, Heitman J. 2004. Cryptococcus neoformans virulence gene discovery through insertional mutagenesis. Eukaryot Cell 3: 420-429.

Idnurm A, Walton FJ, Floyd A, Reedy JL, Heitman J. 2009. Identification of ENA1 as a virulence gene of the human pathogenic fungus Cryptococcus neoformans through signature-tagged insertional mutagenesis. Eukaryot Cell 8: $315-326$.

Ikeda R, Sugita T, Jacobson ES, Shinoda T. 2003. Effects of melanin upon susceptibility of Cryptococcus to antifungals. Microbiol Immunol 47: 271-277.

Jacobson ES, Hong JD. 1997. Redox buffering by melanin and $\mathrm{Fe}(\mathrm{II})$ in Cryptococcus neoformans. J Bacteriol 179: 5340-5346.

Jacobson ES, Ayers DJ, Harrell AC, Nicholas CC. 1982. Genetic and phenotypic characterization of capsule mutants of Cryptococcus neoformans. J Bacteriol 150: 1292-1296.

Janbon G, Himmelreich U, Moyrand F, Improvisi L, Dromer F. 2001. Caslp is a membrane protein necessary for the O-acetylation of the Cryptococcus neoformans capsular polysaccharide. Mol Microbiol 42: 453-467.

Janbon G, Ormerod KL, Paulet D, Byrnes EJ, Yadav V, Chatterjee G, Mullapudi N, Hon C-C, Billmyre R.B, Brunel F et al. 2014. Analysis of the genome and transcriptome of Cryptococcus neoformans var. grubii reveals complex RNA expression and microevolution leading to virulence attenuation. PLos Genet 10: e1004261.

Jung WH, Sham A, White R, Kronstad JW. 2006. Iron regulation of the major virulence factors in the AIDS-associated pathogen Cryptococcus neoformans. PLoS Biol 4: e410.

Jung WH, Sham A, Lian T, Singh A, Kosman DJ, Kronstad JW. 2008. Iron source preference and regulation of iron uptake in Cryptococcus neoformans. PLoS Pathog 4: e45.

Jung WH, Hu G, Kuo W, Kronstad JW. 2009. Role of ferroxidases in iron uptake and virulence of Cryptococcus neoformans. Eukaryot Cell 8: 1511-1520.

Jung WH, Saikia S, Hu G, Wang J, Fung CK, D'Souza C, White R, Kronstad JW. 2010. HapX positively and negatively regulates the transcriptional response to iron deprivation in Cryptococcus neoformans. PLoS Pathog 6: e1001209.

Jung KW, Strain AK, Nielsen K, Jung KH, Bahn YS. 2012. Two cation transporters Enal and Nhal cooperatively modulate ion homeostasis, antifungal drug resistance, and virulence of Cryptococcus neoformans via the HOG pathway. Fungal Genet Biol 49: 332-345.

Kavanaugh LA, Fraser JA, Dietrich FS. 2006. Recent evolution of the human pathogen Cryptococcus neoformans by intervarietal transfer of a 14-gene fragment. Mol Biol Evol 23: $1879-1890$.
Khan ZU, Randawa HS, Sandhu RS. 1977. Carriage of Cryptococcus neoformans in the crops of pigeons. J Med Microbiol 11: 215-218.

Kidd SE, Hagen F, Tscharke RL, Huynh M, Bartlett KH, Fyfe M, Macdougall L, Boekhout T, Kwon-Chung KJ, Meyer W. 2004. A rare genotype of Cryptococcus gattii caused the cryptococcosis outbreak on Vancouver Island (British Columbia, Canada). Proc Natl Acad Sci 101: 17258 17263.

Klengel T, Liang W-J, Chaloupka J, Ruoff C, Schröppel K, Naglik JR, Eckert SE, Mogensen EG, Haynes K, Tuite MF, et al. 2005. Fungal adenylyl cyclase integrates $\mathrm{CO}_{2}$ sensing with cAMP signaling and virulence. Curr Biol 15: 20212026.

Klutts JS, Doering TL. 2008. Cryptococcal xylosyltransferase 1 (Cxt1p) from Cryptococcus neoformans plays a direct role in the synthesis of capsule polysaccharides. J Biol Chem 283: 14327-14334.

Klutts JS, Levery SB, Doering TL. 2007. A $\beta$-1,2-xylosyltransferase from Cryptococcus neoformans defines a new family of glycosyltransferases. J Biol Chem 282: 1789017899.

Kmetzsch L, Staats CC, Simon E, Fonseca FL, de Oliveira DL, Sobrino L, Rodrigues J, Leal AL, Nimrichter L, Rodrigues ML, et al. 2010. The vacuolar $\mathrm{Ca}^{2+}$ exchanger Vcxl is involved in calcineurin-dependent $\mathrm{Ca}^{2+}$ tolerance and virulence in Cryptococcus neoformans. Eukaryotic Cell 9: 1798-1805.

Kmetzsch L, Joffe LS, Staats CC, de Oliveira DL, Fonseca FL, Cordero RJ, Casadevall A, Nimrichter L, Schrank A, Vainstein $\mathrm{MH}$, et al. 2011. Role for Golgi reassembly and stacking protein (GRASP) in polysaccharide secretion and fungal virulence. Mol Microbiol 81: 206-218.

Ko YJ, Yu YM, Kim GB, Lee GW, Maeng PJ, Kim S, Floyd A, Heitman J, Bahn YS. 2009. Remodeling of global transcription patterns of Cryptococcus neoformans genes mediated by the stress-activated HOG signaling pathways. Eukaryot Cell 8: 1197-1217.

Kraus PR, Boily MJ, Giles SS, Stajich JE, Allen A, Cox GM, Dietrich FS, Perfect JR, Heitman J. 2004. Identification of Cryptococcus neoformans temperature-regulated genes with a genomic-DNA microarray. Eukaryot Cell 3: 12491260.

Kronstad JW, Loftus BJ, Lodge JK. 2011. The Cryptococcus genomes: Tools for comparative genomics and expression analysis. In Cryptococcus (ed. Heitman J, et al.), pp. 115126. ASM, Washington, DC.

Kronstad JW, Hu G, Jung WH. 2013. An encapsulation of iron homoestasis and virulence in Cryptococcus neoformans. Trends Microbiol 21: 457-465.

Kumar P, Yang M, Haynes BC, Skowyra ML, Doering TL. 2011. Emerging themes in cryptococcal capsule synthesis. Curr Opin Struct Biol 21: 597-602.

Kwon-Chung KJ. 1975. A new genus, Filobasidiella, the perfect state of Cryptococcus neoformans. Mycologia 67: $1197-1200$.

Kwon-Chung KJ. 1976a. Morphogenesis of Filobasidiella neoformans, the sexual state of Cryptococcus neoformans. Mycologia 68: 821-833.

Kwon-Chung KJ. 1976b. A new species of Filobasidiella, the sexual state of Cryptococcus neoformans B and C serotypes. Mycologia 68: 943-946. 
Kwon-Chung KJ. 1980. Nuclear genotypes of spore chains in Filobasidiella neoformans (Cryptococcus neoformans). Mycologia 72: 418-422.

Kwon-Chung KJ, Bennett JE. 1978. Distribution of a and $\alpha$ mating types of Cryptococcus neoformans among natural and clinical isolates. Am J Epidemiol 108: 337-340.

Kwon-Chung KJ, Bennett JE. 1984. Epidemiologic differences between the two varieties of Cryptococcus neoformans. Am J Epidemiol 120: 123-130.

Kwon-Chung KJ, Bennett JE. 1992. Medical mycology. Lea \& Febiger, Philadelphia.

Kwon-Chung KJ, Rhodes JC. 1986. Encapsulation and melanin formation as indicators of virulence in Cryptococcus neoformans. Infect Immun 51: 218-223.

Kwon-Chung KJ, Bennett JE, Rhodes JC. 1982a. Taxonomic studies of Filobasidiella species and their anamorphs. Antonie Van Leeuwenhoek 48: 25-38.

Kwon-Chung KJ, Polacheck I, Bennett JE. 1982b. Improved diagnostic medium for separation of Cryptococcus neoformans var. neoformans (serotypes A and D) and Cryptococcus neoformans var. gattii (serotypes B and C). J Clin Microbiol 15: 535-537.

Kwon-Chung KJ, Polacheck I, Popkin TJ. 1982c. Melaninlacking mutants of Cryptococcus neoformans and their virulence for mice. J Bacteriol 150: 1414-1421.

Kwon-Chung KJ, Boekhout T, Fell JW, Diaz M. 2002. (1557) Proposal to conserve the name Cryptococcus gattii against C. hondrianus and C. bacillisporus (Basidiomycota, Hymenomycetes, Tremellomycetidae). Taxon 51: 804-806.

Lee H, Bien CM, Hughes AL, Espenshade PJ, Kwon-Chung KJ, Chang YC. 2007. Cobalt chloride, a hypoxia-mimicking agent, targets sterol synthesis in the pathogenic fungus Cryptococcus neoformans. Mol Microbiol 65: 1018-1033.

Lee IR, Chow EW, Morrow CA, Djordjevic JT, Fraser JA. 2011. Nitrogen metabolite repression of metabolism and virulence in the human fungal pathogen Cryptococcus neoformans. Genetics 188: 309-323.

Lin X, Hull CM, Heitman J. 2005. Sexual reproduction between partners of the same mating type in Cryptococcus neoformans. Nature 434: 1017-1021.

Lin X, Huang JC, Mitchell TG, Heitman J. 2006. Virulence attributes and hyphal growth of Cryptococcus neoformans

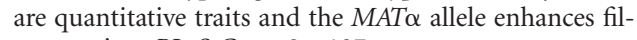
amentation. PLoS Genet 2: e187.

Littman ML, Borok R. 1968. Relation of the pigeon to cryptococcosis: Natural carrier state, heat resistance and survival of Cryptococcus neoformans. Mycopathol Mycol Appl 35: 329-345.

Litvintseva AP, Marra RE, Nielsen K, Heitman J, Vilgalys R, Mitchell TG. 2003. Evidence of sexual recombination among Cryptococcus neoformans serotype A isolates in sub-Saharan Africa. Eukaryot Cell 2: 1162-1168.

Litvintseva AP, Kestenbaum L, Vilgalys R, Mitchell TG. 2005. Comparative analysis of environmental and clinical populations of Cryptococcus neoformans. J Clin Microbiol 43: 556-564.

Liu L, Tewari RP, Williamson PR. 1999. Laccase protects Cryptococcus neoformans from antifungal activity of alveolar macrophages. Infect Immun 67: 6034-6039.

Liu OW, Chun CD, Chow ED, Chen C, Madhani HD, Noble SM. 2008. Systematic genetic analysis of virulence in the
C. neoformans and C. gattii in Cryptococcosis

human fungal pathogen Cryptococcus neoformans. Cell 135: $174-188$

Lodge JK, Jackson-Machelski E, Toffaletti DL, Perfect JR, Gordon JI. 1994. Targeted gene replacement demonstrates that myristoyl-CoA: protein $N$-myristoyltransferase is essential for viability of Cryptococcus neoformans. Proc Natl Acad Sci 91: 12008-12012.

Loftus BJ, Fung E, Roncaglia P, Rowley D, Amedeo P, Bruno D, Vamathevan J, Miranda M, Anderson IJ, Fraser JA, et al. 2005. The genome of the basidiomycetous yeast and human pathogen Cryptococcus neoformans. Science 307: 1321-1324.

MacDougall L, Kidd SE, Galanis E, Mak S, Leslie MJ, Cieslak PR, Kronstad JW, Morshed MG, Bartlett KH. 2007. Spread of Cryptococcus gattii in British Columbia, Canada, and detection in the Pacific Northwest, USA. Emerg Infect Dis 13: 42-50.

Martinez LR, Casadevall A. 2006. Susceptibility of Cryptococcus neoformans biofilms to antifungal agents in vitro. Antimicrob Agents Chemother 50: 1021-1033.

McClelland CM, Chang YC, Varma A, Kwon-Chung KJ. 2004. Uniqueness of the mating system in Cryptococcus neoformans. Trends Microbiol 12: 208-212.

Meyer W, Gilgado F, Ngamskulrungroj P, Trilles LH, Hagen F, Castaneda E, Boekhout T. 2011. Molecular typing of the Cryptococcus neoformans/Cryptococcus gattii species complex. In Cryptococcus: From human pathogen to model yeast (ed. Heitman J, et al.), pp. 327-357. ASM, Washington, DC.

Mitchell TG, Castaneda E, Niersen K, Wanke BMSL. 2011. Environmental niches for Cryptococcus neoformans and Cryptococcus gattii. In Cryptococcus: From human pathogen to model yeast (ed. Heitman J, et al.), pp. 237-259. ASM, Washington, DC.

Mody CH, Toews GB, Lipscomb MF. 1988. Cyclosporin A inhibits the growth of Cryptococcus neoformans in a murine model. Infect Immun 56: 7-12.

Mogensen EG, Janbon G, Chaloupka J, Steegborn C, Fu MS, Moyrand F, Klengel T, Pearson DS, Geeves MA, Buck J, et al. 2006. Cryptococcus neoformans senses $\mathrm{CO}_{2}$ through the carbonic anhydrase Can2 and the adenylyl cyclase Cac1. Eukaryot Cell 5: 103-111.

Morrow CA, Lee IR, Chow EW, Ormerod KL, Goldinger A, Byrnes EJ 3rd, Nielsen K, Heitman J, Schirra HJ, Fraser JA. 2012. A unique chromosomal rearrangement in the Cryptococcus neoformans var. grubii type strain enhances key phenotypes associated with virulence. mBio 3: e00310-11.

Moyrand F, Janbon G. 2004. UGD1, encoding the Cryptococcus neoformans UDP-glucose dehydrogenase, is essential for growth at $37^{\circ} \mathrm{C}$ and for capsule biosynthesis. $\mathrm{Eu}$ karyot Cell 3: 1601-1608.

Moyrand F, Klaproth B, Himmelreich U, Dromer F, Janbon G. 2002. Isolation and characterization of capsule structure mutant strains of Cryptococcus neoformans. Mol Microbiol 45: 837-849.

Moyrand F, Fontaine T, Janbon G. 2007. Systematic capsule gene disruption reveals the central role of galactose metabolism on Cryptococcus neoformans virulence. $\mathrm{Mol} \mathrm{Mi-}$ crobiol 64: 771-781.

Moyrand F, Lafontaine I, Fontaine T, Janbon G. 2008. UGE1 and UGE2 regulate the UDP-glucose/UDP-galactose 
K.J. Kwon-Chung et al.

equilibrium in Cryptococcus neoformans. Eukaryot Cell 7: 2069-2077.

Narasipura SD, Ault JG, Behr MJ, Chaturvedi V, Chaturvedi S. 2003. Characterization of $\mathrm{Cu}, \mathrm{Zn}$ superoxide dismutase (SOD1) gene knock-out mutant of Cryptococcus neoformans var. gattii: Role in biology and virulence. $\mathrm{Mol} \mathrm{Mi-}$ crobiol 47: 1681-1694.

Ngamskulrungroj P, Gilgado F, Faganello J, Litvintseva AP, Leal AL, Tsui KM, Mitchell TG, Vainstein MH, Meyer W. 2009a. Genetic diversity of the Cryptococcus species complex suggests that Cryptococcus gattii deserves to have varieties. PLoS ONE 4: e5862.

Ngamskulrungroj P, Himmelreich U, Breger JA, Wilson C, Chayakulkeeree M, Krockenberger MB, Malik R, Daniel HM, Toffaletti D, Djordjevic JT, et al. 2009b. The trehalose synthesis pathway is an integral part of the virulence composite for Cryptococcus gattii. Infect Immun 77: 4584-4596.

Ngamskulrungroj P, Price J, Sorrell T, Perfect JR, Meyer W. 2011. Cryptococcus gattii virulence composite: candidate genes revealed by microarray analysis of high and less virulent Vancouver island outbreak strains. PLoS ONE 6: e16076.

Ngamskulrungroj P, Chang Y, Hansen B, Bugge C, Fischer E, Kwon-Chung KJ. 2012a. Characterization of the chromosome 4 genes that affect fluconazole-induced disomy formation in Cryptococcus neoformans. PLoS ONE 7: e33022.

Ngamskulrungroj P, Chang Y, Roh J, Kwon-Chung KJ. 2012b. Differences in nitrogen metabolism between Cryptococcus neoformans and C. gattii, the two etiologic agents of cryptococcosis. PLoS ONE 7: e34258.

Ngamskulrungroj P, Chang Y, Sionov E, Kwon-Chung KJ. 2012c. The primary target organ of Cryptococcus gattii is different from that of Cryptococcus neoformans in a murine model. mBio 3: e00103-00112.

Ni M, Feretzaki M, Li W, Floyd-Averette A, Mieczkowski P, Dietrich FS, Heitman J. 2013. Unisexual and heterosexual meiotic reproduction generate aneuploidy and phenotypic diversity de novo in the yeast Cryptococcus neoformans. PLoS Biol 11: e1001653.

Nielson JB, Ivey MH, Bulmer GS. 1978. Cryptococcus neoformans: Pseudohyphal forms surviving culture with Acanthamoeba polyphaga. Infect Immun 20: 262-266.

Nimrichter L, Frases S, Cinelli LP, Viana NB, Nakouzi A, Travassos LR, Casadevall A, Rodrigues ML. 2007. Selfaggregation of Cryptococcus neoformans capsular glucuronoxylomannan is dependent on divalent cations. $E \mathbf{U}$ karyot Cell 6: 1400-1410.

Nosanchuk JD, Casadevall A. 2006. Impact of melanin on microbial virulence and clinical resistance to antimicrobial compounds. Antimicrob Agents Chemother 50: 3519-3528.

Noverr MC, Cox GM, Perfect JR, Huffnagle GB. 2003. Role of PLB1 in pulmonary inflammation and cryptococcal eicosanoid production. Infect Immun 71: 1538-1547.

Odom A, Muir S, Lim E, Toffaletti DL, Perfect J, Heitman J. 1997. Calcineurin is required for virulence of Cryptococcus neoformans. EMBO J 16: 2576-2589.

Olszewski MA, Noverr MC, Chen GH, Toews GB, Cox GM, Perfect JR, Huffnagle GB. 2004. Urease expression by Cryptococcus neoformans promotes microvascular se- questration, thereby enhancing central nervous system invasion. Am J Pathol 164: 1761-1771.

Olszewski MA, Zhang Y, Huffnagle GB. 2010. Mechanisms of cryptococcal virulence and persistence. Future Microbiol 5: 1269-1288.

O'Meara TR, Alspaugh JA. 2012. The Cryptococcus neoformans capsule: A sword and a shield. Clin Microbiol Rev 25: $387-408$.

O'Meara TR, Norton D, Price MS, Hay C, Clements MF, Nichols CB, Alspaugh JA. 2010. Interaction of Cryptococcus neoformans Rim101 and protein kinase A regulates capsule. PLoS Pathog 6: e1000776.

O'Meara TR, Holmer SM, Selvig K, Dietrich F, Alspaugh JA. 2013. Cryptococcus neoformans Rim101 is associated with cell wall remodeling and evasion of the host immune responses. mBio 4: e00522-12.

Osterholzer JJ, Surana R, Milam JE, Montano GT, Chen GH, Sonstein J, Curtis JL, Huffnagle GB, Toews GB, Olszewski MA. 2009. Cryptococcal urease promotes the accumulation of immature dendritic cells and a non-protective T2 immune response within the lung. Am J Pathol 174: 932-943.

Panepinto J, Komperda K, Frases S, Park YD, Djordjevic JT, Casadevall A, Williamson PR. 2009. Sec6-dependent sorting of fungal extracellular exosomes and laccase of Cryptococcus neoformans. Mol Microbiol 71: 1165-1176.

Park BJ, Wannemuehler KA, Marston BJ, Govender N, Pappas PG, Chiller TM. 2009. Estimation of the current global burden of cryptococcal meningitis among persons living with HIV/AIDS. AIDS 23: 525-530.

Park BJ, Lockhart SR, Brandt ME, Chiller TM. 2011. Public health importance of cryptococcal disease: Epidemiology, burden, and control. In Cryptococcus: From human pathogen to model yeast (ed. Heitman J, et al.), pp. 585-593. ASM, Washington, DC.

Paugam A, Dupouy-Camet J, Blanche P, Gangneux JP, Tourte-Schaefer C, Sicard D. 1994. Increased fluconazole resistance of Cryptococcus neoformans isolated from a patient with AIDS and recurrent meningitis. Clin Infect Dis 19: $975-976$.

Perfect JR. 2006. Cryptococcus neoformans: The yeast that likes it hot. FEMS Yeast Res 6: 463-468.

Perfect JR. 2010. Cryptococcus neoformans In Principles and practice of infectious diseases (ed. Mandell GL, et al.), pp. 3287-3303. Churchill Livingstone, Philadelphia.

Perfect JR, Ketabchi N, Cox GM, Ingram CW, Beiser CL. 1993. Karyotyping of Cryptococcus neoformans as an epidemiological tool. J Clin Microbiol 31: 3305-3309.

Perfect JR, Dismukes WE, Dromer F, Goldman DL, Graybill JR, Hamill RJ, Harrison TS, Larsen RA, Lortholary O, Nguyen MH, et al. 2010. Clinical practice guidelines for the management of cryptococcal disease: 2010 update by the infectious diseases society of America. Clin Infect Dis 50: 291-322.

Petter R, Kang BS, Boekhout T, Davis BJ, Kwon-Chung KJ. 2001. A survey of heterobasidiomycetous yeasts for the presence of the genes homologous to virulence factors of Filobasidiella neoformans, CNLAC1 and CAP59. Microbiol 147: 2029-2036.

Pfaller MA, Lodge JK, Ghannoum MA. 2011. Drug resistance in Cryptococcus: Epidemiology and molecular 
mechanisms. In Cryptococcus: From human pathogen to model yeast (ed. Heitman J, et al.), pp. 203-216. ASM, Washington, DC.

Polacheck I, Hearing VJ, Kwon-Chung KJ. 1982. Biochemical studies of phenoloxidase and utilization of catecholamines in Cryptococcus neoformans. J Bacteriol 150: $1212-1220$.

Posteraro B, Sanguinetti M, Sanglard D, La Sorda M, Boccia S, Romano L, Morace G, Fadda G. 2003. Identification and characterization of a Cryptococcus neoformans ATP binding cassette $(\mathrm{ABC})$ transporter-encoding gene, CnAFR1, involved in the resistance to fluconazole. $\mathrm{Mol}$ Microbiol 47: 357-371.

Pukkila-Worley R, Gerrald QD, Kraus PR, Boily MJ, Davis MJ, Giles SS, Cox GM, Heitman J, Alspaugh JA. 2005. Transcriptional network of multiple capsule and melanin genes governed by the Cryptococcus neoformans cyclic AMP cascade. Eukaryot Cell 4: 190-201.

Reese AJ, Doering TL. 2003. Cell wall $\alpha-1,3$-glucan is required to anchor the Cryptococcus neoformans capsule. Mol Microbiol 50: 1401-1409.

Reese AJ, Yoneda A, Breger JA, Beauvais A, Liu H, Griffith CL, Bose I, Kim MJ, Skau C, Yang S, et al. 2007. Loss of cell wall $\alpha(1-3)$ glucan affects Cryptococcus neoformans from ultrastructure to virulence. Mol Microbiol 63: 1385-1398.

Rhodes JC, Polacheck I, Kwon-Chung KJ. 1982. Phenoloxidase activity and virulence in isogenic strains of Cryptococcus neoformans. Infect Immun 36: 1175-1184.

Rivera J, Feldmesser M, Cammer M, Casadevall A. 1998. Organ-dependent variation of capsule thickness in Cryptococcus neoformans during experimental murine infection. Infect Immun 66: 5027-5030.

Rodero L, Mellado E, Rodriguez AC, Salve A, Guelfand L, Cahn P, Cuenca-Estrella M, Davel G, Rodriguez-Tudela JL. 2003. G484S amino acid substitution in lanosterol $14-\alpha$ demethylase (ERG11) is related to fluconazole resistance in a recurrent Cryptococcus neoformans clinical isolate. Antimicrob Agents Chemother 47: 3653-3656.

Rodrigues ML, Djordjevic JT. 2012. Unravelling secretion in Cryptococcus neoformans: More than one way to skin a cat. Mycopathologia 173: 407-418.

Rodrigues ML, Alvarez M, Fonseca FL, Casadevall A. 2008 Binding of the wheat germ lectin to Cryptococcus neoformans suggests an association of chitinlike structures with yeast budding and capsular glucuronoxylomannan. Eukaryot Cell 7: 602-609.

Rosa e Silva LK, Staats CC, Goulart LS, Morello LG, Pelegrinelli Fungaro MH, Schrank A, Vainstein MH. 2008. Identification of novel temperature-regulated genes in the human pathogen Cryptococcus neoformans using representational difference analysis. Res Microbiol 159: 221 229.

Ruiz A, Nielsen JB, Bulmer GS. 1981. Control of Cryptococcus neoformans in nature by biotic factors. Sabouraudia 20: $21-29$.

Saijo T, Chen J, Chen SC-A, Rosen LB, Yi J, Sorrell TC, Bennett JE, Holland SM, Brown SK, Kwon-Chung KJ. 2014. AntiGM-CSF autoantibodies are a risk factor for central nervous system infection by Cryptococcus gattii in otherwise immunocompetent patients. mBio 5: e00912-14.

Salas SD, Bennett JE, Kwon-Chung KJ, Perfect JR, Williamson PR. 1996. Effect of the laccase gene CNLAC1, on
C. neoformans and C. gattii in Cryptococcosis

virulence of Cryptococcus neoformans. J Exp Med 184: $377-386$.

Salyer WR, Salyer DC, Baker RD. 1974. Primary complex of Cryptococcus and pulmonary lymph nodes. J Infect Dis 130: 74-77.

Samson RA, Stalpers JA, Weijman AC. 1983. On the taxonomy of the entomogenous fungus Filobasidiella arachnophila. Antonie Van Leeuwenhoek 49: 447-456.

Sanfelice F. 1894. Contributo alla morphologia e biologia dei blastomiceti che si sviluppano nei succhi di alcuni frutti [Contribution on the morphology and biology of blastomyces that grows in certain fruit juice]. Ann Igien 4: 463495.

Sarosi GA, Parker JD, Doto IL, Tosh FE. 1969. Amphotericin $\mathrm{B}$ in cryptococcal meningitis. Long-term results of treatment. Ann Intern Med 71: 1079-1087.

Schneider RdO, Fogaça NdS S, Kmetzsch L, Schrank A, Vainstein MH, Staats CC. 2012. Zap1 regulates zinc homeostasis and modulates virulence in Cryptococcus gattii. PLoS ONE 7: e43773.

Seeliger HPR. 1956. Use of a urease test for the screening and identification of cryptococci. J Bacteriol 72: 127-131.

Shi M, Li SS, Zheng C, Jones GJ, Kim KS, Zhou H, Kubes P, Mody CH. 2010. Real-time imaging of trapping and urease-dependent transmigration of Cryptococcus neoformans in mouse brain. J Clin Invest 120: 1683-1693.

Singh A, Panting RJ, Varma A, Saijo T, Waldron KJ, Jong A, Ngamskulrungroj P, Chang YC, Rutherford JC, KwonChung KJ. 2013. Factors required for activation of urease as a virulence determinant in Cryptococcus neoformans. mBio 4: e00220-13.

Sionov E, Chang YC, Garraffo HM, Kwon-Chung KJ. 2009. Heteroresistance to fluconazole in Cryptococcus neoformans is intrinsic and associated with virulence. Antimicrob Agents Chemother 53: 2804-2815.

Sionov E, Lee H, Chang YC, Kwon-Chung KJ. 2010. Cryptococcus neoformans overcomes stress of azole drugs by formation of disomy in specific multiple chromosomes. PLoS Pathog 6: e1000848.

Sionov E, Chang YC, Garraffo HM, Dolan MA, Ghannoum MA, Kwon-Chung KJ. 2012. Identification of a Cryptococcus neoformans cytochrome P450 lanosterol $14 \alpha-$ demethylase (Erg11) residue critical for differential susceptibility between fluconazole/voriconazole and itraconazole/posaconazole. Antimicrob Agents Chemother 56: $1162-1169$.

Sionov E, Chang YC, Kwon-Chung KJ. 2013. Azole heteroresistance in Cryptococcus neoformans: Emergence of resistant clones with chromosomal disomy in the mouse brain during fluconazole treatment. Antimicrob Agents Chemother 57: 5127-5130.

Sorrell TC, Chen SCA, Phillips P, Marr KA. 2011. Clinical perspectives on Cryptococcus neoformans and Cryptococcus gattii: Implications for diagnosis and management. In Cryptococcus: From human pathogen to model yeast (ed. Heitman J, et al.), pp. 595-606. ASM, Washington, DC.

Staib F. 1962a. Cryptococcus neoformans beim Kanarienvogel. $Z$ Bacteriol 185: 129-134.

Staib F. 1962b. Cryptococcus neoformans und Guizotia abyssinica (Syn G. oleifera) Farbreaktion für Cr. neoformans [Cryptococcus neoformans and Guizotia abyssinica (Syn 
K.J. Kwon-Chung et al.

G. oleifera) color reaction for Cr. neoformans]. Z Hyg 148: $466-475$.

Staib F, Mishra SK, Able T, Blisse A. 1976. Growth of Cryptococcus neoformans on uric acid agar. Z Bakteriol 236: 374-385.

Stanton BC, Giles SS, Staudt MW, Kruzel EK, Hull CM. 2010. Allelic exchange of pheromones and their receptors reprograms sexual identity in Cryptococcus neoformans. PLoS Genet 6: e1000860.

Steen BR, Lian T, Zuyderduyn S, MacDonald WK, Marra M, Jones SJ, Kronstad JW. 2002. Temperature-regulated transcription in the pathogenic fungus Cryptococcus neoformans. Genome Res 12: 1386-1400.

Steenbergen JN, Shuman HA, Casadevall A. 2001. Cryptococcus neoformans interactions with amoebae suggest an explanation for its virulence and intracellular pathogenic strategy in macrophages. Proc Natl Acad Sci 98: 1524515250 .

Steinbach WJ, Reedy JL, Cramer RA Jr., Perfect JR, Heitman J. 2007. Harnessing calcineurin as a novel anti-infective agent against invasive fungal infections. Nat Rev Microbiol 5: 418-430.

Stephen C, Lester S, Black W. 2002. Multispecies outbreak of cryptococcosis on southern Vancouver Island, British Columbia. Can J Vet Res 43: 792-794.

Stoddard JL, Cutler EC. 1916. Torula infection in man, Vol. 6, pp. 1-98. Rockefeller Institute for Medical Research, New York.

Sun S, Xu J. 2009. Chromosomal rearrangements between serotype A and D strains in Cryptococcus neoformans. PLoS ONE 4: e5524.

Swinne-Desgain D. 1975. Cryptococcus neoformans of saprophytic origin. Sabouraudia 13: 303-308.

Tangen KL, Jung WH, Sham AP, Lian T, Kronstad JW. 2007. The iron- and cAMP-regulated gene SIT1 influences ferrioxamine $B$ utilization, melanization and cell wall structure in Cryptococcus neoformans. Microbiol 153: 29-41.

Toffaletti DL, Rude TH, Johnston SA, Durack DT, Perfect JR. 1993. Gene transfer in Cryptococcus neoformans by use of biolistic delivery of DNA. J Bacteriol 175: 1405-1411.

Torres-Guererro H, Edman JC. 1994. Melanin-deficient mutants of Cryptococcus neoformans. J Med Vet Mycol 32: 303-313.

Vaishnav VV, Bacon BE, O'Neill M, Cherniak R. 1998. Structural characterization of the galactoxylomannan of Cryptococcus neoformans Cap67. Carbohydr Res 306: 315-330.

van Duin D, Casadevall A, Nosanchuk JD. 2002. Melanization of Cryptococcus neoformans and Histoplasma capsulatum reduces their susceptibilities to amphotericin $\mathrm{B}$ and caspofungin. Antimicrob Agents Chemother 46: 3394-3400.

van Duin D, Cleare W, Zaragoza O, Casadevall A, Nosanchuk JD. 2004. Effects of voriconazole on Cryptococcus neoformans. Antimicrob Agents Chemother 48: 2014-2020.

Varma A, Kwon-Chung KJ. 2010. Heteroresistance of Cryptococcus gattii to fluconazole. Antimicrob Agents Chemother 54: 2303-2311.

Vartivarian SE, Anaissie EJ, Cowart RE, Sprigg HA, Tingler MJ, Jacobson ES. 1993. Regulation of cryptococcal cap sular polysaccharide by iron. J Infect Dis 167: 186-190.
Versé M. 1914. Uber einen Fall von generalisierter Blastomykose beim menschen [About a case of generalized human blastomycosis]. Verh Dtsch Pathol Ges 17: $275-$ 278.

Vuillemin P. 1901. Les blastomycetes pathogens. Rev Gen Sci Pures Appl 12: 732-751.

Walton FJ, Idnurm A, Heitman J. 2005. Novel gene functions required for melanization of the human pathogen Cryptococcus neoformans. Mol Microbiol 57: 1381-1396.

Wang Y, Casadevall A. 1994. Susceptibility of melanized and nonmelanized Cryptococcus neoformans to nitrogen- and oxygen-derived oxidants. Infect Immun 62: 3004-3007.

Wang Y, Aisen P, Casadevall A. 1995. Cryptococcus neoformans melanin and virulence: Mechanism of action. Infect Immun 63: 3131-3136.

Wang ZA, Griffith CL, Skowyra ML, Salina N, Williams M, Maier EJ, Gish SR, Liu H, Brent MR, Doering TL. 2014. The dual GDP-mannose transporters of Cryptococcus neoformans and their role in biology and virulence. $\mathrm{Eu}$ karyot Cell 13: 832-842.

Warpeha KM, Park YD, Williamson PR. 2013. Susceptibility of intact germinating Arabidopsis thaliana to human fungal pathogens Cryptococcus neoformans and C. gattii. Appl Environ Microbiol 79: 2979-2988.

Waterman SR, Hacham M, Hu G, Zhu X, Park Y-D, Shin S, Panepinto J, Valyi-Nagy T, Beam C, Husain S, et al. 2007a. Role of a CUF1/CTR4 copper regulatory axis in the virulence of Cryptococcus neoformans. J Clin Invest 117: 794-802.

Waterman SR, Hacham M, Panepinto J, Hu G, Shin S, Williamson PR. 2007b. Cell wall targeting of laccase of Cryptococcus neoformans during infection of mice. Infect Immun 75: 714-722.

Waterman SR, Park Y-D, Raja M, Qiu J, Hammoud DA, O'Halloran TV, Williamson PR. 2012. Role of CTR4 in the virulence of Cryptococcus neoformans. mBio 3: e00285-12.

Whitney LC, Bicanic T. 2014. Treatment principles for Candida and Cryptococcus. Cold Spring Harb Perspect Med doi: 10.1101/cshperspect.a024158.

Wills EA, Roberts IS, Del Poeta M, Rivera J, Casadevall A, Cox GM, Perfect JR. 2001. Identification and characterization of the Cryptococcus neoformans phosphomannose isomerase-encoding gene, MAN1, and its impact on pathogenicity. Mol Microbiol 40: 610-620.

Wilson DE, Bennett JE, Bailey JW. 1968. Serologic grouping of Cryptococcus neoformans. Proc Soc Exp Biol Med 127: 820-823.

Wozniak KL, Olszewski M, Wormley FL. 2012. Host immune responses against pulmonary fungal pathogens, pp. 85127. InTech, Rijeka, Croatia.

Wright LC, Santangelo RM, Ganendren R, Payne J, Djordjevic JT, Sorrell TC. 2007. Cryptococcal lipid metabolism: Phospholipase B1 is implicated in transcellular metabolism of macrophage-derived lipids. Eukaryot Cell 6: 37-47.

Xu J, Ali RY, Gregory DA, Amick D, Lambert SE, Yoell HJ, Vilgalys RJ, Mitchell TG. 2000. Uniparental mitochondrial transmission in sexual crosses in Cryptococcus neoformans. Curr Microbiol 40: 269-273. 
Xu J-P, Manosuthi W, Banerjee U. 2011. Cryptococcosis in Asia. In Cryptococcus: From human pathogen to model yeast (ed. Heitman J, et al.), pp. 287-297. ASM, Washington, DC.

Xue C, Tada Y, Dong X, Heitman J. 2007. The human fungal pathogen Cryptococcus can complete its sexual cycle during a pathogenic association with plants. Cell Host Microbe 1: 263-273.

Yan Z, Hull CM, Heitman J, Sun S, Xu J. 2004. SXI1 $\alpha$ controls uniparental mitochondrial inheritance in Cryptococcus neoformans. Curr Biol 14: R743-R744.

Yang J, Li D, Liu X, Pan J, Yan B, Zhu X. 2010. Regulation of virulence factors, carbon utilization and virulence by SNF1 in Cryptococcus neoformans JEC21 and divergent
C. neoformans and C. gattii in Cryptococcosis

actions of SNF1 between cryptococcal strains. Fungal Genet Biol 47: 994-1000.

Yoneda A, Doering TL. 2006. A eukaryotic capsular polysaccharide is synthesized intracellularly and secreted via exocytosis. Mol Biol Cell 17: 5131-5140.

Zhu X, Williamson PR. 2004. Role of laccase in the biology and virulence of Cryptococcus neoformans. FEMS Yeast Res 5: 1-10.

Zhu X, Gibbons J, Garcia-Rivera J, Casadevall A, Williamson PR. 2001. Laccase of Cryptococcus neoformans is a cell wallassociated virulence factor. Infect Immun 69: 5589-5596.

Zhu P, Zhai B, Lin X, Idnurm A. 2013. Congenic strains for genetic analysis of virulence traits in Cryptococcus gattii. Infect Immun 81: 2616-2625. 


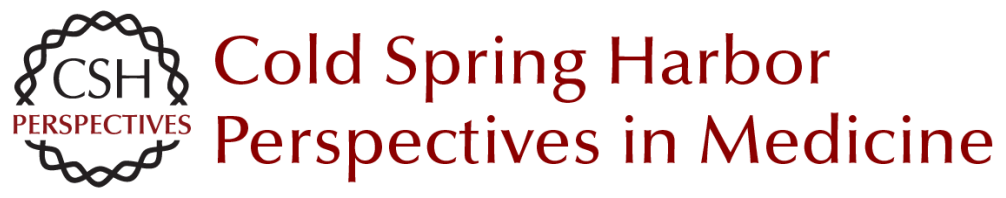

\section{Cryptococcus neoformans and Cryptococcus gattii, the Etiologic Agents of Cryptococcosis}

Kyung J. Kwon-Chung, James A. Fraser, Tamara L. Doering, Zhuo A. Wang, Guilhem Janbon, Alexander Idnurm and Yong-Sun Bahn

Cold Spring Harb Perspect Med 2014; doi: 10.1101/cshperspect.a019760

Subject Collection Human Fungal Pathogens

\section{Evolutionary Perspectives on Human Fungal \\ Pathogens John W. Taylor}

Black Molds and Melanized Yeasts Pathogenic to Humans Anuradha Chowdhary, John Perfect and G. Sybren de Hoog

Fungal Pathogens: Survival and Replication within Macrophages Andrew S. Gilbert, Robert T. Wheeler and Robin C. May

Innate Defense against Fungal Pathogens Rebecca A. Drummond, Sarah L. Gaffen, Amy G. Hise, et al.

Antifungal Pharmacokinetics and Pharmacodynamics Alexander J. Lepak and David R. Andes

Human Fungal Pathogens of Mucorales and Entomophthorales Leonel Mendoza, Raquel Vilela, Kerstin Voelz, et al.

Functional Profiling of Human Fungal Pathogen Genomes Alexi I. Goranov and Hiten D. Madhani

\section{Aspergillus fumigatus and Related Species} Janyce A. Sugui, Kyung J. Kwon-Chung, Praveen R. Juvvadi, et al.
Thermally Dimorphic Human Fungal Pathogens--

Polyphyletic Pathogens with a Convergent

Pathogenicity Trait

Anita Sil and Alex Andrianopoulos

Mechanisms of Antifungal Drug Resistance Leah E. Cowen, Dominique Sanglard, Susan J. Howard, et al.

Treatment Principles for Candida and Cryptococcus Laura C. Whitney and Tihana Bicanic

The Human Mycobiome Patrick C. Seed

Treatment Principles for the Management of Mold Infections

Dimitrios P. Kontoyiannis and Russell E. Lewis

Adaptive Immunity to Fungi Akash Verma, Marcel Wüthrich, George Deepe, et al.

The Candida Pathogenic Species Complex Siobhán A. Turner and Geraldine Butler

Fungal Morphogenesis Xiaorong Lin, J. Andrew Alspaugh, Haoping Liu, et al.

For additional articles in this collection, see http://perspectivesinmedicine.cshlp.org/cgi/collection/ 